\title{
Insulin Dysfunction Induces In Vivo Tau Hyperphosphorylation through Distinct Mechanisms
}

\author{
Emmanuel Planel, ${ }^{1,4}$ Yoshitaka Tatebayashi, ${ }^{1,2}$ Tomohiro Miyasaka, ${ }^{1,3}$ Li Liu, ${ }^{4}$ Lili Wang, ${ }^{4}$ Mathieu Herman, ${ }^{4}$ \\ W. Haung Yu, ${ }^{4}$ Jose A. Luchsinger, ${ }^{5}$ Brian Wadzinski, ${ }^{6}$ Karen E. Duff, ${ }^{4}$ and Akihiko Takashima ${ }^{1}$ \\ ${ }^{1}$ Laboratory for Alzheimer's Disease, Brain Science Institute, The Institute of Physical and Chemical Research, Saitama 351-0198, Japan, ${ }^{2}$ Depression \\ Project, Mood Disorder Research Team, Tokyo Institute of Psychiatry, Tokyo 156-8585, Japan, ${ }^{3}$ Department of Neuropathology, Faculty of Medicine, \\ University of Tokyo, Tokyo 113-0033, Japan, ${ }^{4}$ Department of Pathology, Taub Institute for Alzheimer's Disease Research, Columbia University Medical \\ Center, ${ }^{5}$ Columbia University, New York, New York 10032, and ${ }^{6}$ Vanderbilt University Medical Center, Nashville, Tennessee 37232
}

Hyperphosphorylated tau is the major component of paired helical filaments in neurofibrillary tangles found in Alzheimer's disease (AD) brains, and tau hyperphosphorylation is thought to be a critical event in the pathogenesis of the disease. The large majority of AD cases is late onset and sporadic in origin, with aging as the most important risk factor. Insulin resistance, impaired glucose tolerance, and diabetes mellitus (DM) are other common syndromes in the elderly also strongly age dependent, and there is evidence supporting a link between insulin dysfunction and AD. To investigate the possibility that insulin dysfunction might promote tau pathology, we induced insulin deficiency and caused DM in mice with streptozotocin (STZ). A mild hyperphosphorylation of tau could be detected 10, 20, and $30 \mathrm{~d}$ after STZ injection, and a massive hyperphosphorylation of tau was observed after $40 \mathrm{~d}$. The robust hyperphosphorylation of tau was localized in the axons and neuropil, and prevented tau binding to microtubules. Neither mild nor massive tau phosphorylation induced tau aggregation. Body temperature of the STZ-treated mice did not differ from control animals during $30 \mathrm{~d}$, but dropped significantly thereafter. No change in $\beta$-amyloid (A $\beta$ ) precursor protein (APP), APP C-terminal fragments, or A $\beta$ levels were observed in STZ-treated mice; however, cellular protein phosphatase $2 \mathrm{~A}$ activity was significantly decreased. Together, these data indicate that insulin dysfunction induced abnormal tau hyperphosphorylation through two distinct mechanisms: one was consequent to hypothermia; the other was temperature-independent, inherent to insulin depletion, and probably caused by inhibition of phosphatase activity.

Key words: Alzheimer's disease; tau hyperphosphorylation; $\beta$-amyloid precursor protein; insulin deficiency; streptozotocin; diabetes mellitus; hypothermia; kinase; serine/threonine protein phosphatase; PP2A; GSK-3; cdk5; JNK; MAPK; CaMKII

\section{Introduction}

Alzheimer's disease $(\mathrm{AD})$ brains are characterized by extracellular aggregates of the $\beta$-amyloid peptide $(\mathrm{A} \beta)$ (Glenner and Wong, 1984), and intraneuronal neurofibrillary tangles (NFTs), composed of hyperphosphorylated tau protein assembled in paired helical filaments (PHFs) (Grundke-Iqbal et al., 1986). Tau hyperphosphorylation can induce aggregation (Alonso et al., 2001; Sato et al., 2002), and is thought to induce NFTs and neurodegeneration in AD (Trojanowski and Lee, 1994). However, the causes of tau hyperphosphorylation in $\mathrm{AD}$ are not well understood.

Only a small proportion of $\mathrm{AD}$ is attributable to genetic variants, the large majority of cases is late onset and sporadic in

Received March 15, 2007; revised 0ct. 17, 2007; accepted 0ct. 18, 2007.

This work was supported by National Institutes of Health/New York University Alzheimer's Disease Center Pilot Project Grant AG008051 (E.P.) and National Institute of Neurological Disorders and Stroke Grant NS048447 (K.E.D.). We thank Drs. Peter Davies (Albert Einstein University, New York, NY), Yasuo Ihara (Tokyo University, Tokyo, Japan), Sonia Jung (Centocor R\&D, Radnor, PA), and Paul Mathews (Nathan Kline Institute/New York University, Orangeburg, NY) for the generous gift of antibodies.

Correspondence should be addressed to Dr. Emmanuel Planel, Columbia University Medical Center, Department of Pathology, Taub Institute for Alzheimer's Disease Research, Black Building \#5-513, 650 West 168th Street, New York, NY 10032. E-mail: emmanuel@planel.org.

DOI:10.1523/JNEUROSCI.3949-07.2007

Copyright $\odot 2007$ Society for Neuroscience $\quad 0270-6474 / 07 / 2713635-14 \$ 15.00 / 0$ origin. Aging is considered to be the most important risk factor for $\mathrm{AD}$ (Harman, 2002). Other common syndromes in the elderly, diabetes mellitus (DM), impaired glucose tolerance, insulin resistance, and relative decrease of pancreas endocrine activity and insulin secretion, are also associated with aging (Lamberts et al., 1997). Moreover, insulin signaling seems to be involved in the modulation of lifespan and brain aging (Cole and Frautschy, 2007).

There is increasing evidence to support a link between $\mathrm{AD}$ and insulin dysfunction. Compared with age-matched controls, AD patients show reduced CSF insulin (Craft et al., 1998), impaired insulin-like signal transduction (Frolich et al., 1999), decreased brain insulin and insulin-like growth factor I expression and function (Rivera et al., 2005), and reduced glucose metabolism (Mosconi, 2005). From these observations, it was suggested that brain insulin signaling dysfunction and the possible consequent reduction in glucose metabolism are crucial in the genesis of $\mathrm{AD}$ (Meier-Ruge and Bertoni-Freddari, 1996; Salehi and Swaab, 1999; Heininger, 2000; Hoyer, 2000, 2002; Gasparini et al., 2002; Watson and Craft, 2003). Insulin dysfunction is a feature of DM, and, although AD and DM were first found to be strongly associated or mutually exclusive in a series of conflicting epidemiological studies (Finch and Cohen, 1997), many longitudinal 
population-based studies detected higher $\mathrm{AD}$ incidences rates in diabetic patients (Biessels et al., 2006). In addition, insulin can act as a neurotrophic and regulatory peptide in human brain, and is capable of modulating tau phosphorylation in neuronal cultures (Hong and Lee, 1997; Lesort et al., 1999; Lesort and Johnson, 2000). Despite all these data, very little is known on the effects of insulin dysfunction on tau phosphorylation in vivo.

To investigate the role of insulin dysfunction on tau phosphorylation, we deprived the mice of insulin by injections of streptozotocin (STZ), which induces experimental DM by specifically destroying the pancreatic islets of Langerhans (Tjalve, 1983). In contrast with many peripheral tissues, brain insulin binding and insulin receptors levels are not upregulated during experimental DM (Pacold and Blackard, 1979; Sechi et al., 1992; Pezzino et al., 1996), which leads to lower brain insulin content (Figlewicz et al., 1983; Frank et al., 1986). Our data indicate that insulin dysfunction induced by STZ results in tau hyperphosphorylation through two distinct mechanisms: one is consequent to hypothermia and induced by impaired glucose/energy metabolism; the other is temperature-independent, inherent to insulin deficiency, and induced by inhibition of Ser/Thr phosphatases activities.

\section{Materials and Methods \\ Animals \\ C57BL/6NJcl adult mice of either sex (Clea, Tokyo, Japan) ranging from 3 to 6 months of age were used in these studies. Younger animals were avoided, because juvenile rodents tend to develop hypothermia very rap- idly after injection of streptozotocin (Howarth et al., 2005). Mice were maintained in a temperature-controlled room $\left(\sim 23^{\circ} \mathrm{C}\right)$ with a $12 \mathrm{~h}$ light/ dark cycle, and experiments were performed during the light period. Animals were handled according to procedures approved by the Institu- tional Animal Care and Use Committee of the Institute of Physical and Chemical Research. The body temperature of the animals was monitored using a rectal probe (Thermalert TH-5; Physitemp, Clifton, NJ).}

Streptozotocin injections, insulin pumps implantation, plasma glucose, and insulin quantification

Batches of four, nonfasted animals with food and water ad libitum were injected intraperitoneally with $200 \mathrm{mg} / \mathrm{kg}$ of STZ (Sigma, St. Louis, MO) freshly dissolved in $0.05 \mathrm{M}$ citrate buffer, $\mathrm{pH} 4.5$; control mice were injected with citrate buffer. STZ is used at various doses to induce experimental diabetes (Weber et al., 1984), usually after a period of fasting, which was avoided here because fasting can induce tau hyperphosphorylation (Planel et al., 2001). The dose for our studies was specifically chosen to avoid induction of progressive diabetes mellitus (with normal serum insulin levels) that can occur in mice with lower doses. For example, one injection of $100 \mathrm{mg} / \mathrm{kg}$ can induce non-insulin-dependent DM, whereas one injection of $200 \mathrm{mg} / \mathrm{kg}$ induces insulin-dependent DM (Ito et al., 1999). Brains were collected 10,20,30, or $40 \mathrm{~d}$ after injection, and analyzed as described below. To reverse the effect of STZ, $3 \mathrm{~d}$ after injection, mice were implanted with subcutaneous osmotic pumps delivering $0.75 \mathrm{U} / \mathrm{d}$ insulin (Humulin R; Eli Lilly, Indianapolis, IN) according to a protocol modified from Cuthbertson et al. (1988). Pump implantation completely reversed diabetic symptoms in mice treated with a single intraperitoneal injection of $250 \mathrm{mg} / \mathrm{kg}$ of STZ (Cuthbertson et al., 1988). Plasma glucose was determined using the mutarotase-glucose oxydase method according to the manufacturer's instructions (Autokit Glucose; Wako Pure Chemical, Osaka, Japan). Plasma insulin was determined using a sandwich enzyme immunoassay according to the manufacturer's instructions (mouse insulin kit; Shibayagi, Gunma, Japan).

\section{Analysis of tau solubility}

Mice were killed by cervical dislocation, brains were immediately removed, and tissues were dissected on ice. Hemispheres (hippocampus and neocortex) were quickly weighed, frozen on dry ice, and kept at $-80^{\circ} \mathrm{C}$. Tau solubility was analyzed by a modification of the protocol of
Greenberg and Davies (1990) (Noble et al., 2005). Briefly, frozen hemispheres were homogenized without thawing in $5 \times(\mathrm{v} / \mathrm{w})$ RIPA buffer $(50$ mM Tris-HCl, pH 7.4, 1\% NP-40, 0.25\% Na-deoxycholate, $150 \mathrm{~mm} \mathrm{NaCl}$, $1 \mathrm{~mm}$ EDTA, 1 mм PMSF, 1 mм Na $\mathrm{VO}_{4}, 1 \mathrm{~mm} \mathrm{NaF}, 1 \mu \mathrm{g} / \mathrm{ml}$ aprotinin, leupeptin, and pepstatin) with a mechanical microhomogenizer (Physcotron NS-310E; Microtek, Chiba, Japan), and centrifuged at 20,000 $\times$ $g$ for $20 \mathrm{~min}$ at $4^{\circ} \mathrm{C}$. An aliquot of the supernatant representing the total tau fraction was kept for analysis. The heat-stable, aggregate-free fraction was obtained by boiling another aliquot for $5 \mathrm{~min}$ and removing protein aggregates by spinning at $20,000 \times g$ for $20 \mathrm{~min}$ at $4^{\circ} \mathrm{C}$. The rest of the supernatant was adjusted to $1 \%$ Sarkosyl ( $N$-lauroylsarcosine), incubated for $30 \mathrm{~min}$ at room temperature with constant shaking, and centrifuged at $100,000 \times g$ for $1 \mathrm{~h}$ at $20^{\circ} \mathrm{C}$. The pellet containing Sarkosylinsoluble aggregated tau was resuspended and analyzed by SDS-PAGE. Tau in the Sarkosyl pellet has been shown by immunoelectron microscopy to be filamentous (Noble et al., 2003), and it is synonymous with that identified by immunohistochemistry in NFTs. All three fractions were diluted in $\mathrm{O}+$ buffer [ $62.5 \mathrm{~mm}$ Tris- $\mathrm{HCl}, \mathrm{pH} 6.8,10 \%$ glycerol, $5 \%$ 2-mercaptoethanol, 2.3\% SDS, 1 mm EGTA, 1 mM EDTA, 1 mM PMSF, 1 $\mathrm{mm} \mathrm{Na} \mathrm{VO}_{4}, 1 \mathrm{~mm} \mathrm{NaF}, 10 \mu \mathrm{l} / \mathrm{ml}$ protease inhibitor mixture P8340 (Sigma)], a modified O buffer (O'Farrell, 1975), boiled for $3 \mathrm{~min}$, and kept at $-20^{\circ} \mathrm{C}$.

\section{Microtubule binding assay}

The microtubule (MT)-binding assay was performed as described previously (Maas et al., 2000), with a few modifications. Hemispheres were homogenized in $5 \times(\mathrm{w} / \mathrm{v})$ BRB80 (Brinkley Reassembly Buffer; $80 \mathrm{~mm}$ PIPES/KOH, pH 6.8, 1 mM EGTA, $1 \mathrm{~mm} \mathrm{MgCl}_{2}$ ) with protease and phosphatase inhibitors. Homogenates were incubated on ice for $15 \mathrm{~min}$ and centrifuged at $20,000 \times g$ for $20 \mathrm{~min}$ at $4^{\circ} \mathrm{C}$. Supernatants were respun at $100,000 \times g$ for $1 \mathrm{~h}$ at $4^{\circ} \mathrm{C}$. Equal amounts of protein lysate were used in each binding assay. High-speed supernatants were adjusted to 1 mM GTP and $10 \mu \mathrm{m}$ taxol and incubated with taxol-stabilized microtubules (30 $\mu \mathrm{m}$; Cytoskeleton, Denver, CO) in a final volume of $50 \mu \mathrm{l}$ for 10 $\mathrm{min}$ at $37^{\circ} \mathrm{C}$. The mixtures were centrifuged through $100 \mu \mathrm{l}$ of $30 \%$ (w/v) sucrose cushions in BRB80 containing $1 \mathrm{~mm}$ GTP and $10 \mu \mathrm{M}$ taxol, at $100,000 \times g$ for $30 \mathrm{~min}$ at room temperature. The supernatant (MT-free fraction) was collected and diluted with $\mathrm{O}+$ buffer, and the pellet (MTbound fraction) was resuspended in $\mathrm{O}+$ buffer.

\section{Protein extraction}

Mice were killed by cervical dislocation, brains were immediately removed, and tissues were dissected on ice. Hemispheres (hippocampus and neocortex) were quickly weighed, frozen on dry ice, and maintained at $-80^{\circ} \mathrm{C}$ until they were homogenized without thawing in $5 \times(\mathrm{v} / \mathrm{w})$ RIPA buffer with a mechanical microhomogenizer. Samples were then centrifuged for $20 \mathrm{~min}$ at $100,000 \times g$ at $4^{\circ} \mathrm{C}$, diluted in $\mathrm{O}+$ buffer, and boiled for $3 \mathrm{~min}$. Depending on the antibody used, 7-14 $\mu \mathrm{g}$ of protein were analyzed as described previously (Planel et al., 2001).

\section{Antibodies}

The anti-tau PHF-1 (phospho-Ser-396/404) monoclonal antibody was a generous gift from Dr. Peter Davies (Albert Einstein University, New York, NY). Total tau was detected with either Tau T57120 (monoclonal; BD Transduction Laboratories, San Jose, CA) or Tau A0024 (polyclonal; DakoCytomation, Carpinteria, CA). AT8 and AT180 (Pierce Biotechnology, Rockford, IL) reacts with tau phosphorylated at Ser-202 and Thr205 (Goedert et al., 1995), and tau phosphorylated at Thr-231 (Goedert et al., 1994), respectively. Tau-1 (Chemicon International, Temecula, CA) recognizes tau dephosphorylated at Ser-195, Ser-198, Ser-199, and Ser-202 (Szendrei et al., 1993). Purified rabbit polyclonal anti-tau antibodies anti-tau pS199, pS262, pS356, pS400, and pS422 were purchased from Biosource International (Camarillo, CA). Anti-microtubuleassociated protein 2 (MAP2) antibody was kindly provided by Dr. Yasuo Ihara (Tokyo University, Tokyo, Japan). Changes in the expression and phosphorylation of tau kinases were investigated with the following antibodies: cyclin-dependent kinase 5 (cdk-5), p35C, calcium/calmodulindependent kinase II (CaMKII), phospho-CaMKII (Santa Cruz Biotechnology, Santa Cruz, CA); glycogen synthase kinase $3 \beta$ (GSK-3 $\beta$ ) (BD Transduction Laboratories); anti-GSK-3 $\alpha / \beta$ [pY219/pY216] (Biosource 
International), phospho-GSK-3 $\beta$ (Ser9), stress-activated protein kinase (SAPK)/c-Jun N-terminal kinase (JNK), phospho-SAPK/JNK (T183/ Y185) G9, p44/42 mitogen-activated protein kinase (MAPK), phosphop44/42 MAPK (T202/Y204) (Cell Signaling Technology, Danvers, MA). Levels of protein phosphatases were analyzed with the following antibodies: protein phosphatase 1 (PP1) (E-9) and PP2A-A (H-300) from Santa Cruz Biotechnology; PP2B (calcineurin A) from R\&D Systems (Minneapolis, MN); PP2A-C (7A6) from Upstate Biotechnology (Lake Placid, $\mathrm{NY}$ ); PP2A B $\alpha$ and B $\beta$ were described previously (Strack et al., 1998). For $\mathrm{A} \beta$ precursor protein (APP) and $\mathrm{A} \beta$ analysis, the following antibodies were used: C1/6.1 anti-APP full-length and C-terminal fragments (CTFs) (Mathews et al., 2002) (generous gift from Dr. Paul Mathews, Nathan Kline Institute/New York University, Orangeburg, NY); and JRF/cA $\beta 40$ and JRF/cA $\beta 42 / 26$ (murine $A \beta 1-40$ and $A \beta 1-42$, respectively; generous gift from Dr. Sonia Jung, Centocor R\&D, Radnor, PA).

\section{Western blot analysis and ELISA}

Membrane blocking and antibody incubations were performed as described previously (Planel et al., 2001), with appropriate primary and secondary antibody dilutions. Anti-mouse and anti-rabbit HRPconjugated secondary antibodies were purchased from Jackson ImmunoResearch (West Grove, PA). Immunoreactive bands were visualized and analyzed by enhanced chemiluminescence reagent (SuperSignal West Pico or Femto; Pierce Biotechnology) using a Fujifilm LAS3000 imaging system and the Image Gauge Mac OS X software. Serial dilutions of brain extracts were loaded in gels to obtain calibration curves for reliable quantification. ELISAs for soluble murine $\mathrm{A} \beta 40$ and $\mathrm{A} \beta 42$ were performed as described previously, using diethyl acetate extracts from fresh hemibrains (Burns et al., 2003; Schmidt et al., 2005).

\section{Immunohistochemistry}

Tissue fixation was done according to the "cold Bouin's method" (Planel et al., 2004). This procedure minimizes postmortem tau dephosphorylation in mice brains (our unpublished observations). Briefly, mice were killed by cervical dislocation, and the brain was quickly removed and immersed in ice-cold Bouin's solution (saturated picric acid, formalin, acetic acid at 15:5:1), for $24 \mathrm{~h}$ and then embedded in paraffin blocks. Eight- to $10-\mu \mathrm{m}$-thick sections were processed for immunohistochemical analyses. Deparaffinized and hydrated sections were incubated in Target Retrieval Solution (DakoCytomation) at $70^{\circ} \mathrm{C}$ for $25 \mathrm{~min}$ for enhancement of the immunoreactivity, and then incubated in $10 \%$ normal goat serum in PBS at $4^{\circ} \mathrm{C}$ for $2 \mathrm{~h}$. The specimens were incubated in primary antibodies diluted in 1\% BSA in PBS containing 0.05\% of Tween 20 overnight at $4^{\circ} \mathrm{C}$. Bound antibodies were visualized with Alexa 488conjugated anti-mouse or Alexa 568-conjugated anti-rabbit IgG (Invitrogen, Eugene, OR). Immunolabeled tissues were observed under an Olympus (Tokyo, Japan) BX50 microscope equipped with an Olympus DP50 digital CCD camera and the Studio Lite 1.0 software (Pixera Corporation, Tokyo, Japan).

\section{Phosphatases activities}

The effect of STZ injections on brain phosphatase activities was determined using three different assays.

Endogenous tau dephosphorylation assay. This assay was performed as described previously (Planel et al., 2007). Briefly, control or $10 \mathrm{~d}$ STZtreated mice were killed by cervical dislocation, brains were immediately removed, and one hemisphere (hippocampus and neocortex) was homogenized in $5 \times(\mathrm{v} / \mathrm{w})$ phosphatase sample buffer [ $50 \mathrm{~mm}$ Tris- $\mathrm{HCl}, \mathrm{pH}$ 7.5, $0.25 \mathrm{~m}$ sucrose, $10 \mathrm{~mm}$ 2-mercaptoethanol, $0.1 \mathrm{~mm}$ EDTA, $1 \mathrm{~mm}$ benzamidine, $1 \mathrm{~mm}$ PMSF, $10 \mu \mathrm{l} / \mathrm{ml}$ protease inhibitor mixture P8340 Sigma)]. The supernatant was diluted $10 \times$ in phosphatase assay buffer [50 mм Tris-HCl, pH 7.0, 0.1 mм EDTA, 5 mм DTT, 0.01\% Brij 35, 1 mм PMSF, $10 \mu \mathrm{l} / \mathrm{ml}$ protease inhibitor mixture P8340 (Sigma)], incubated at $37^{\circ} \mathrm{C}$, and sampled at different intervals. Endogenous PHF-1 phosphorylation levels were monitored by Western blotting.

Phosphatase assay with synthetic peptide. To verify the results from the above phosphatase assay, we performed a PP2A assay using the Serine/ Threonine Phosphatase Assay System from Promega (Madison, WI) (V2460). Briefly, mice were killed by cervical dislocation, brain was immediately removed, and one hemisphere (hippocampus and neocortex) was homogenized in $5 \times(\mathrm{v} / \mathrm{w})$ phosphatase sample buffer and immediately processed as indicated by the manufacturer to remove particulate matter and endogenous free phosphate. For PP2A activity, $2.0 \mu \mathrm{l}$ of the resulting solution was prepared in duplicate, and the release of phosphate from a chemically synthesized phosphopeptide was assessed over a period of $10 \mathrm{~min}$ in PP2A buffer at $37^{\circ} \mathrm{C}$ (calibration data not shown). The amount of phosphate released was measured by the absorbance of the molybdate-malachite green-phosphate complex at $630 \mathrm{~nm}$.

PP2A immunoprecipitation assay. We performed this assay with the PP2A Immunoprecipitation Phosphatase BioAssay kit from US Biological (Swampscott, MA), according to the manufacturer's instructions. Briefly, brain hemispheres were homogenized in $40 \times(\mathrm{v} / \mathrm{w})$ of $20 \mathrm{~mm}$ imidazole-HCl, pH 7.0, 2 mм EDTA, 2 mм EGTA, 1 mm PMSF, $10 \mu \mathrm{l} / \mathrm{ml}$ protease inhibitor mixture P8340 (Sigma), and centrifuged at $2000 \times g$ for $5 \mathrm{~min}$ at $4^{\circ} \mathrm{C}$. PP2A catalytic subunit was immunoprecipitated from the supernatant with a monoclonal antibody and protein A-agarose for $2 \mathrm{~h}$ at $4^{\circ} \mathrm{C}$. The activity of the immunoprecipitated PP2A was assessed by the release of phosphate from a chemically synthesized phosphopeptide over a period of $10 \mathrm{~min}$ at $30^{\circ} \mathrm{C}$. The amount of phosphate released was measured by the absorbance of the molybdate-malachite greenphosphate complex at $630 \mathrm{~nm}$.

\section{Statistical analysis}

Except for Figure 10A, in which a two-way ANOVA was performed, statistical analysis was performed by one-way ANOVA. Significant factors from the ANOVA $(p<0.05)$ were followed by Dunnett's or TukeyKramer's post hoc tests. Data are means \pm SD. The asterisks indicate significant differences versus control as follows: ${ }^{*} p<0.05,{ }^{* *} p<0.01$, and ${ }^{* * *} p<0.001$.

\section{Results}

\section{Effect of diabetes on tau pathology}

We first investigated whether STZ treatment influences tau pathology by investigating tau phosphorylation and solubility in animals sampled 10, 20, 30, and $40 \mathrm{~d}$ after one injection of STZ. There was a mild increase in tau phosphorylation at AT8 (pS202 and pT205) and PHF-1 (pS396 and pS404) epitopes in the total tau fraction at 10, 20, and $30 \mathrm{~d}$ (Fig. $1 A a, A b$ ), and a massive hyperphosphorylation after $40 \mathrm{~d}$ (Fig. $1 \mathrm{Aa}$ ), whereas phosphoindependent tau protein did not change (Fig. $1 A c$ ). Note that the AT8 immunoblots are overexposed to reveal the mild hyperphosphorylation during the first $30 \mathrm{~d}$, and that the data at $40 \mathrm{~d}$ are not included in the statistical analysis because they are outside of the linear range. Tau levels and phosphorylation in the heat-stable fraction were more variable, but displayed the same trend of mild tau phosphorylation during the first $30 \mathrm{~d}$, followed by massive hyperphosphorylation $40 \mathrm{~d}$ after STZ injection (Fig. $1 \mathrm{~B}$ ). Examination of the Sarkosyl-insoluble fraction did not reveal the presence of aggregated tau in the STZ-treated nontransgenic mice (Fig. 1C, lanes 1-15). A transgenic hTau mouse hemibrain was extracted at the same time and used as positive control (Fig. 1C, lane 16), because these mice develop tau pathology in the cortex (Andorfer et al., 2003). Thus, induction of diabetes in nontransgenic mice leads to a biphasic phosphorylation of tau, with a mild hyperphosphorylation for the first $30 \mathrm{~d}$ and a massive one after $40 \mathrm{~d}$. However, aggregated tau was not observed in either phase.

\section{Impact of diabetes on tau binding to microtubules}

Tau is a microtubule-associated protein whose function is to bind an stabilize MTs, and tau binding to MTs is regulated by phosphorylation (Avila et al., 2004). We therefore investigated the effect of diabetes on tau binding to MTs. Despite the mild tau hyperphosphorylation observed during the first $30 \mathrm{~d}$ after STZ injection, there was no change in tau binding to MTs (Fig. 2A). However, the massive tau hyperphosphorylation occurring at $40 \mathrm{~d}$ impaired tau binding to MTs, as revealed by $\sim 40 \%$ less tau 
in the MT-bound fraction (Fig. 2Ab). There was also $\sim 20 \%$ more tau in the MTfree fraction, but this increase did not reach significance. Equal loading of MTs was confirmed by examining the levels of $\alpha$-tubulin in the different fractions (Fig. $2 B$ ). Thus, only the massive hyperphosphorylation observed at $40 \mathrm{~d}$ had a significant effect on tau binding to MTs.

\section{Streptozotocin treatment induces tau hyperphosphorylation at multiple epitopes}

Having shown that tau phosphorylation in response to STZ treatment was biphasic, with a mild hyperphosphorylation during the first $30 \mathrm{~d}$ and a massive one at $40 \mathrm{~d}$, we concentrated additional analysis on one representative point of the first phase and one of the second phase: another set of mice was treated with STZ and sampled at 10 and $40 \mathrm{~d}$ after treatment. Tau phosphorylation was investigated by semiquantitative Western blot using an extensive panel of anti-tau antibodies. An increase of tau phosphorylation at the phospho-serine 199 (pS199) and PHF-1 (pS396 and pS404) epitopes was observed after $10 \mathrm{~d}$, and at all the phospho-epitopes studied after $40 \mathrm{~d}$ (Fig. 3). In fact, most of the epitopes investigated here were hyperphosphorylated after $10 \mathrm{~d}$, but this is not visible in Figure 3 because the blots were exposed to be in the linear range for quantification of the results at $40 \mathrm{~d}$. The hyperphosphorylation specific to STZ treatment after $10 \mathrm{~d}$ at Tau-1, AT8, and AT180 epitopes can be seen in Figures 1, 6, and 7. Early phosphorylation at PS199 is particularly interesting because this epitope enables the visualization of early stages of tau pathology, even when aggregates of tau are not detectable by biochemical approaches (Maurage et al., 2003). Furthermore, detection of PS199 in the CSF can be used in the antemortem diagnostic of $\mathrm{AD}$ (Itoh et al., 2001). AT8 (pS202 and pT205) and pS422 epitopes were also highly phosphor-

ylated. AT8 is considered an early marker of tau dysfunction, whereas pS422 is characteristic of abnormal, AD-like tau phosphorylation (Matsuo et al., 1994; Hasegawa et al., 1996; Bussiere et al., 1999). Thus, STZ-induced insulin dysfunction can rapidly lead to a biochemical pattern of tau phosphorylation similar to that seen in early AD. The STZ-induced changes in tau phosphorylation appear to occur in two phases. First, a mild hyperphosphorylation as observed at $10 \mathrm{~d}$ (up to $300 \%$ increase), followed by a massive hyperphosphorylation at $40 \mathrm{~d}(>15,000 \%$ increase at some epitopes).

\section{Hyperphosphorylated tau is limited to the neuropil} and axons

We then examined the gross anatomical pattern of tau phosphorylation. There were no evident differences in the pattern of tau
STZ STZ STZ
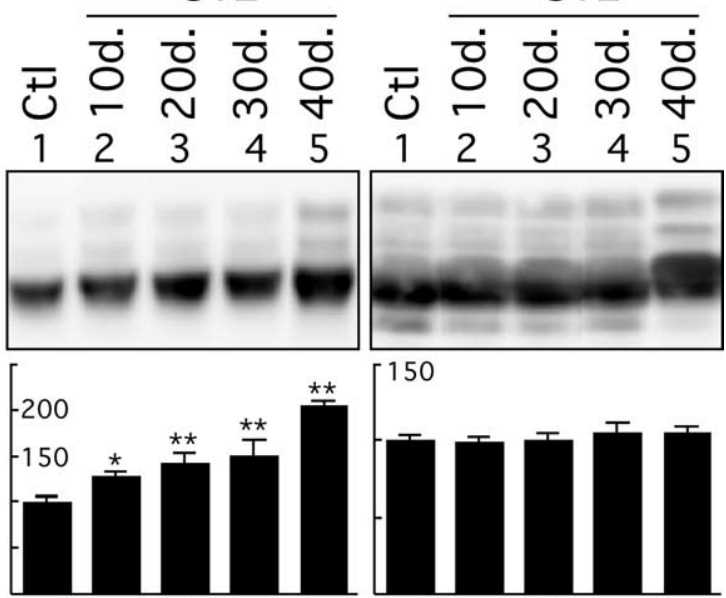

b. Total PHF-1

150

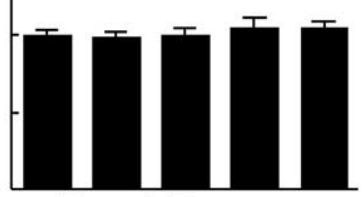

c. Total Tau

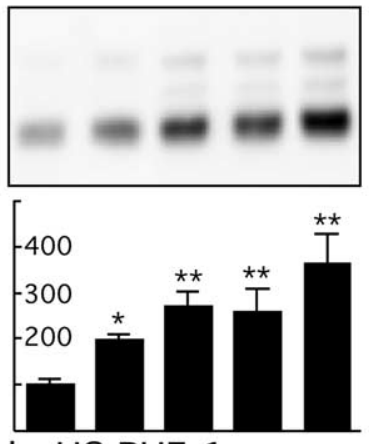

b. HS PHF-1
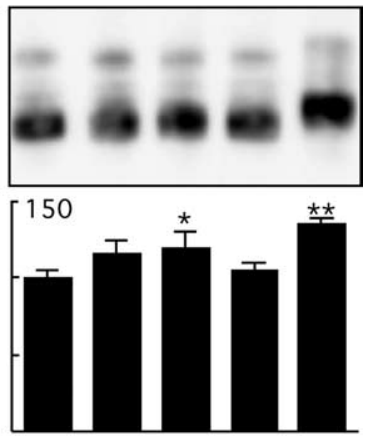

c. HS Tau

Figure 1. Immunoblot analysis of tau solubility after streptozotocin treatment. Brain proteins (hippocampus and neocortex) from control mice and mice treated for 10, 20,30, and $40 \mathrm{~d}$ were extracted according to a modified method of Greenberg and munoblot analysis with the following antibodies: AT8 (pS202/pT205), PHF-1 (pS396/pS404), and Tau (phospho-independent). which they are aligned. Data represented are means \pm SD $(n=3$ for each condition; 1 representative data displayed; each lane represents an individual mouse). The asterisks indicate significant differences from controls as follows: ${ }^{*} p<0.05$ and ${ }^{* *} p<0.01$.

phosphorylation $10 \mathrm{~d}$ after STZ treatment (data not shown). At $40 \mathrm{~d}$, tau was hyperphosphorylated at AT8 in most anterior areas, such as the neocortex and hippocampus (Fig. $4 A, B$ ). The pattern of total tau axonal (fimbria, alveus, and mossy fibers, for example) and neuropil staining was not altered after STZ treatment (Fig. 4C,D). Immunostaining for pS199 (Fig. 4E,F) and PHF-1 (Fig. $4 G, H$ ) epitopes was not visibly altered in response to STZ. These results confirm our Western blot data, which revealed large changes in tau phosphorylation at the AT8 epitope (Fig. 3Ac, Bc) in response to $40 \mathrm{~d}$ of STZ, but smaller changes in phosphorylation at the PS199 and PHF-1 epitopes, which could already be observed in control animals (Fig. $3 A b, A g, B b, B g$ ). In the hippocampus, hyperphosphorylated tau mainly localized in the neuropil and the axonal tracks of the fimbria, as demonstrated by double staining with AT8 and MAP2 antibodies (Fig. 4I-N). In 

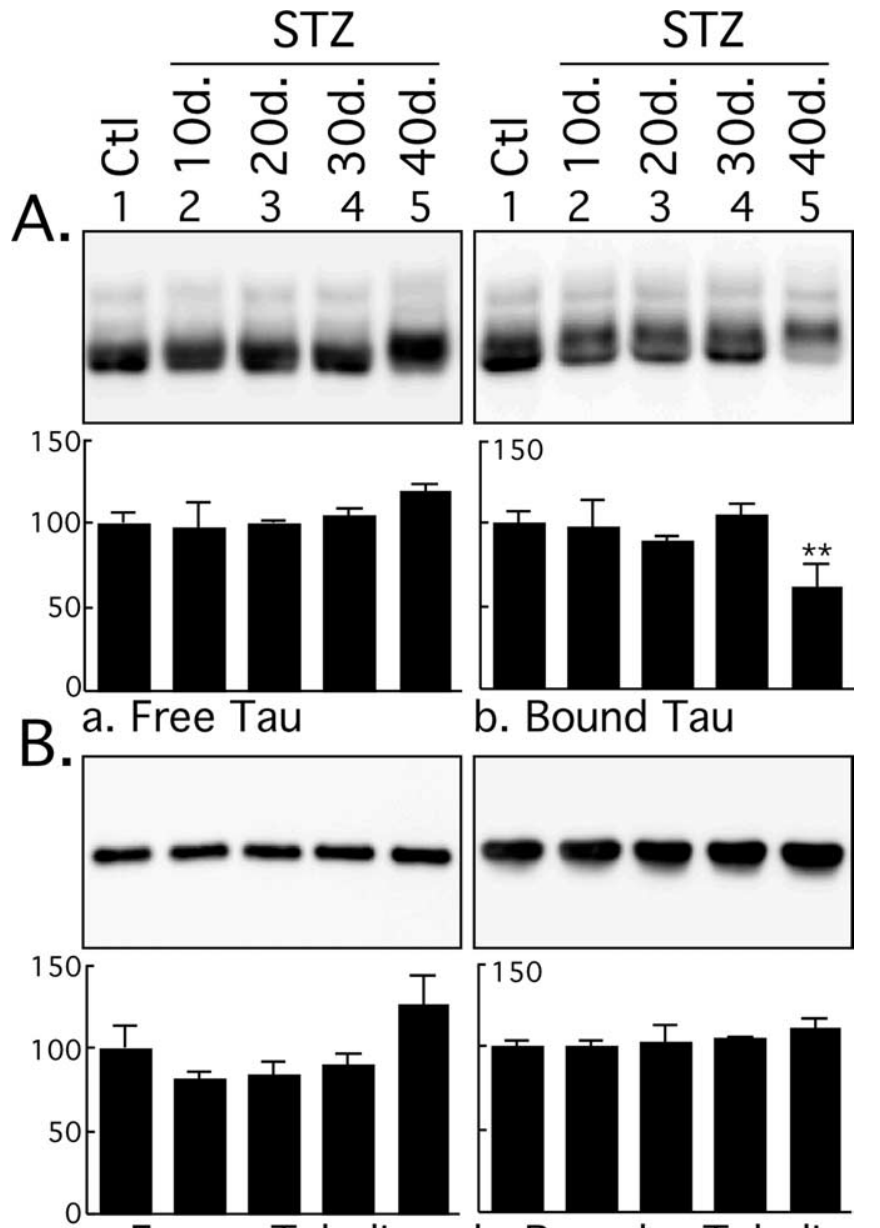

b. Bound Tau

a. Free $\alpha$-Tubulin

Figure 2. Microtubule binding assay of tau after streptozotocin injection. Brain proteins (hippocampus and neocortex) from control mice and mice treated for 10,20,30, and $40 \mathrm{~d}$ were extracted and incubated with taxol-stabilized microtubules. Tau and tubulin levels from MTfree and -bound fractions were evaluated by immunoblot analysis with the following antibodies: Tau (phospho-independent) $(\boldsymbol{A}) ; \alpha$-tubulin (B). The bar graphs represent the quantification of the immunoblot bands displayed above them. Each graph displays the immunoreactivity expressed as a percentage of the control (100\%). The numbers in the graphs indicate the percentage of the tick line with which they are aligned. Data represented are means \pm SD $(n=$ 3 for each condition; 1 representative data displayed; each lane represents an individual mouse). The asterisks indicate significant differences from controls as follows: ${ }^{* *} p<0.01$.

the normal adult brain, tau is an axonal protein, whereas MAP2 is present in the soma and dendrites, but not in the axons. In contrast, tau is found in cell bodies and dendrites of affected neurons in $\mathrm{AD}$. In diseased brains, tau-positive dystrophic axons are widespread and can be easily detected in the alveus and fimbria of the hippocampus (Su et al., 1993). In fact, the earliest detectable hyperphosphorylated tau in $\mathrm{AD}$ is preferentially localized in neurites of vulnerable neurons before extending to the soma ( $\mathrm{Su}$ et al., 1994) where NFTs are formed (Bancher et al., 1989; Braak et al., 1994; Trojanowski and Lee, 1994). Thus, insulin dysfunction appears to induce axonal and neuropil tau hyperphosphorylation, reminiscent of incipient $\mathrm{AD}$, but without observable somatodendritic relocalization.

Insulin dysfunction induces two types of tau hyperphosphorylation

We previously demonstrated that alterations of glucose metabolism can induce hypothermia leading to tau hyperphosphorylation (Planel et al., 2004). Thus, we looked for a possible hypother- mic effect of STZ and its correlation with tau hyperphosphorylation. The temperature of the mice was $\sim 37.5 \pm 0.5^{\circ} \mathrm{C}$ for the first $26 \mathrm{~d}$ and began to drop nonsignificantly thereafter: $37.0 \pm 0.5^{\circ} \mathrm{C}$ at $28 \mathrm{~d}$, and $36.8 \pm 0.7^{\circ} \mathrm{C}$ at $30 \mathrm{~d}$. However, after $30 \mathrm{~d}$, the drop in temperature was significant and reached $31.4 \pm 2.5^{\circ} \mathrm{C}$ at $40 \mathrm{~d}$ (Fig. $5 A$ ). Hypothermia correlated with the massive phosphorylation of tau at $40 \mathrm{~d}$ (Figs. 1, 3), but not with the mild tau phosphorylation observed while the animals were still normothermic (Fig. 3, lanes 1 and 2, pS199 and PHF-1; Fig. 6, lanes 1-4, all the phospho-epitopes). These temperature data were confirmed in the new batch of STZ-treated mice, which displayed hypothermia at $40 \mathrm{~d}$ but not at $10 \mathrm{~d}$ (Fig. $5 B)$. STZ-treated mice displayed hyperglycemia from $10 \mathrm{~d}$ onward after injection, with insulin below detection levels (Fig. 5B). Thus, STZ treatment induced two types of tau hyperphosphorylation: one is probably consequent to hypothermia induced by DM; the other is possibly temperature-independent and specific to hypoinsulinemia.

We also injected young mice (6 weeks of age) with $150 \mathrm{mg} / \mathrm{kg}$ STZ, to confirm previously published data that young rodents tend to develop hypothermia very rapidly after injection of streptozotocin (Howarth et al., 2005). Two days after STZ injection, the animals began to be significantly hypothermic (Ctl, $37.6 \pm$ $\left.0.2^{\circ} \mathrm{C} ; 2 \mathrm{~d}, 36.7 \pm 0.4^{\circ} \mathrm{C} ; 3 \mathrm{~d}, 35.9 \pm 0.5^{\circ} \mathrm{C}\right)$, and by $10 \mathrm{~d}$ they reached $34.2 \pm 1.2^{\circ} \mathrm{C}$, a temperature attained $38 \mathrm{~d}$ after STZ treatment in the adults (Fig. 5). Hypothermia is a powerful regulator of tau phosphorylation, and a $1{ }^{\circ} \mathrm{C}$ drop in body temperature can bring about a 100\% increase of AT8 signal (Planel et al., 2007). Thus, young animals are not suitable to discriminate the effect of hypoinsulinemia from hypothermia.

\section{Prevention of hypothermia partially rescues} tau hyperphosphorylation

To explore the role of temperature on tau phosphorylation in the 40-d-treated mice, we placed the STZ-treated animals at in a ventilated incubator at $37^{\circ} \mathrm{C}$ for $2 \mathrm{~h}$ before sampling. Animals incubated at $37^{\circ} \mathrm{C}$ had rectal temperature equivalent to the control group, did not became hyperthermic (data not shown). Tau hyperphosphorylation was partially, but not completely reversed, as can be seen in the overexposed blots of Figure 6. It is important to note that, in other models of mouse hypothermia, placement of animals at $37^{\circ} \mathrm{C}$ completely rescues tau phosphorylation (Planel et al., 2004, 2007). Thus, $40 \mathrm{~d}$ after STZ treatment, tau hyperphosphorylation can only be partially rescued by restoring normothermia, which suggest that the temperatureindependent, hypoinsulinemia-specific mild hyperphosphorylation observed at $10 \mathrm{~d}$ is still present after $40 \mathrm{~d}$.

\section{Insulin treatment prevents early tau hyperphosphorylation}

Recently, direct injections of STZ in the brain have been shown to increase phospho-tau immunoreactivity (Lester-Coll et al., 2006; Grunblatt et al., 2007), raising the possibility that our observations could be the consequence of infiltration of peripheral STZ in the brain, rather than an effect of peripheral insulin deficit per se. To exclude this possibility, we implanted subcutaneous insulin pumps in mice $3 \mathrm{~d}$ after STZ injection, and analyzed the brains $7 \mathrm{~d}$ later (for a total of $10 \mathrm{~d}$ STZ treatment). Our data show that insulin treatment totally blocked the mild tau hyperphosphorylation of all the epitopes studied (Fig. 7). Thus, early and mild tau hyperphosphorylation in STZ-treated mice is a consequence of hypoinsulinemia rather than a direct effect of STZ on the brain. This is consistent with the fact that peripheral STZ does not impact directly on the brain because its transport and cytotoxicity 
are dependent on the GLUT-2 glucose transporter (Schnedl et al., 1994), which is not expressed at the blood-brain barrier (Simpson et al., 1999).

STZ-induced tau hyperphosphorylation is not attributable to kinase activation We have presented evidence that shows STZ treatment can induce two types of overlapping tau hyperphosphorylation: a mild and early one, specific to insulin dysfunction, and a second one, robust, late, and consequent to hypothermia. We next investigated the molecular mechanisms underlying these two events. Among the kinases able to phosphorylate tau in vitro, GSK-3 $\beta$, cdk5, MAPK/ERK (extracellular signal-regulated kinase), and JNK are considered to be major physiological and pathological tau kinases (Maccioni et al., 2001; Planel et al., 2002; Zhu et al., 2002). CaMKII is also thought to have a major role in regulating the phosphorylation of tau at epitopes that modulate the binding of tau to microtubules (Litersky et al., 1996; Sironi et al., 1998). We explored the activation patterns of these five kinases with antibodies recognizing different activation state of the kinases. Phosphorylation of GSK-3 $\beta$ at Tyr216 facilitates substrate binding, whereas phosphorylation at Ser9 leads to partial inhibition. In the brain, cdk5 forms a heterodimer complex with the neuron specific activator, p35, or p35 cleaved product, p25. JNK and MAPK are activated by double phosphorylation at Thr183/Tyr185 and Thr202/Tyr204, respectively. CaMKII is activated by autophosphorylation at Thr286. No change at GSK-3 $\beta$ pY216 epitope was observed during experimentally induced diabetes (Fig. $8 A a, B a$ ), but a significant increase of pS9 phosphorylation could be detected $40 \mathrm{~d}$ but not $10 \mathrm{~d}$ after treatment (Fig. $8 \mathrm{Ab}, \mathrm{Bb}$ ). CaMKII was highly phosphorylated at its activation site from $10 \mathrm{~d}$ onward (Fig. $8 A d, B c$ ), and a slight but significant CaMKII increase could be detected (Fig. $8 \mathrm{Ae}$ ). Activation of JNK could be detected after $40 \mathrm{~d}$ but not after $10 \mathrm{~d}$ (Fig. $8 A f, B d$ ), and MAPK was not significantly activated during the treatment (Fig. $8 A h, B e$ ). There were no significant changes in either total GSK-3 $\beta$ (Fig. $8 A c$ ), total JNK (Fig. $8 A f$ ), or total MAPK (Fig. $8 A i$ ). There were no significant changes in cdk5 and p35 after STZ treatment (Fig. $8 A j, A k, B f, B g$ ), and there was no detectable p25. Thus, CaMKII was the only kinase to be activated $10 \mathrm{~d}$ after treatment. These results confirm and extend previous observations of elevated CaMKII activity and expression in STZ-treated rat brains (Bhardwaj and Kaur, 1999). However, there was no specific hyperphosphorylation of tau at CaMKII epitopes (pS262 and pS356) independently of other epitopes (Fig. 3Ae,Af, lanes 1 and 2), suggesting that CaMKII overactivation does not have a direct impact on tau phosphorylation during STZ treatment. Nevertheless, we cannot rule out that elevation of CaMKII activation could have an indirect effect on tau by affecting the activity of other kinases or phosphatases. The elevation of GSK-3 $\beta$ S9 inhibitory and of JNK activating phosphorylation at $40 \mathrm{~d}$ can be attributed to hypothermia, because JNK and GSK-3 $\beta$ S9 phosphorylation are a constant feature of hypothermia in mouse brain during metabolic stress (Planel et al., 2004) or anesthesia (Planel et al., 2007). Thus, specific kinase overactivation is probably not the primary mechanism leading to tau hyperphosphorylation at either 10 or $40 \mathrm{~d}$ after STZ treatment.

\section{PP2A subunits change during diabetes}

Because our results failed to adequately explain the extent of tau hyperphosphorylation specific to insulin dysfunction in terms of kinases activation, we next examined the levels and activities of tau Ser/Thr PPs. PPs are classified into four types, PP1, PP2A, $\mathrm{PP} 2 \mathrm{~B}$, and $\mathrm{PP} 2 \mathrm{C}$, on the basis of their substrate specificities and sensitivity to specific activators and inhibitors (Cohen, 1989). We looked first at levels of PP1, PP2A, and PP2B (calcineurin), because biochemical studies have demonstrated that they can dephosphorylate, whereas PP2C cannot (Gong et al., 1994; Tian and Wang, 2002). PP1 and PP2B catalytic subunit levels did not change during the course of the experiment (Fig. $9 A a, A c, B a, B c$ ). However, PP2A C catalytic subunit showed a significant increase from $10 \mathrm{~d}$ of STZ treatment onward (Fig. $9 A b, B b$ ). PP2A is a heterotrimeric holoenzyme consisting of a core dimer composed 

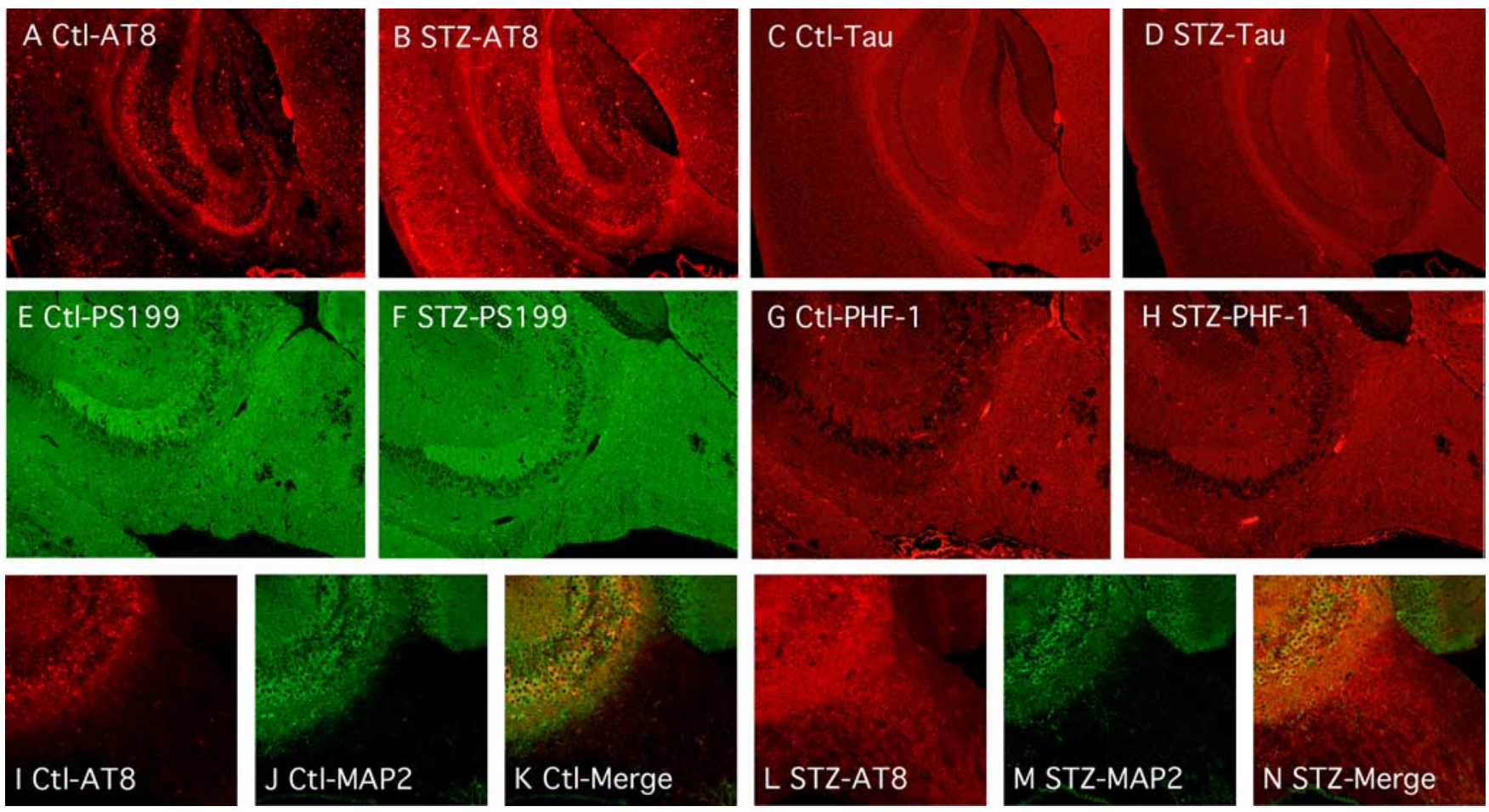

Figure 4. Regional anatomical analysis of tau phosphorylation during anesthesia. Fluorescence photomicrographs of sagittal sections are shown. $A-D, A T 8$ and total Tau immunostaining from control $(\boldsymbol{A}, \boldsymbol{C})$ and $\operatorname{STZ}(\boldsymbol{B}, \boldsymbol{D})$ mice, in the hippocampus and cortical regions ( $40 \times$ magnification). $\boldsymbol{E}-\boldsymbol{H}, \mathrm{PS} 199$ and PHF-1 immunostaining from control $(\boldsymbol{E}, \boldsymbol{G})$ and $\operatorname{STZ}(\boldsymbol{F}, \boldsymbol{H})$ mice, in the hippocampal region (100× magnification). $\boldsymbol{I}-\boldsymbol{N}$, AT8 $(\boldsymbol{I}, \boldsymbol{L}), \operatorname{MAP2}(\boldsymbol{J}, \boldsymbol{M})$, and merged images $(\boldsymbol{K}, \boldsymbol{N})$ from control $(\boldsymbol{I}-\boldsymbol{K})$ and STZ $(\boldsymbol{L}-\boldsymbol{N})$ mice, in the hippocampal region (100 $\times$ magnification).

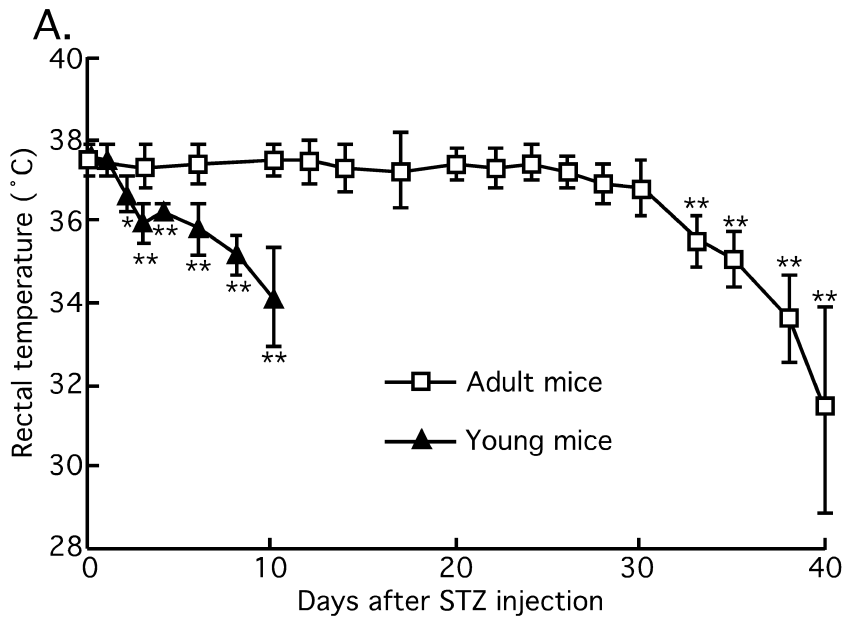

B.

\begin{tabular}{|l|l|l|l|}
\hline & Glucose $(\mathbf{m g} / \mathbf{d l})$ & Insulin $(\mathbf{n g} / \mathbf{m l})$ & \multicolumn{1}{|c|}{ Temp. $\left.^{\circ}{ }^{\circ} \mathbf{C}\right)$} \\
\hline Ctl & $200 \pm 32$ & $1.1 \pm 0.7$ & $37.2 \pm 0.2$ \\
STZ 10 d. & $773 \pm 61^{* *}$ & ND & $37.1 \pm 0.2$ \\
STZ 40 d. & $645 \pm 42 * *$ & ND & $31.9 \pm 0.9 * *$ \\
\hline
\end{tabular}

Figure 5. Time course of the effects of streptozotocin treatment on physiological parameters. $A$, Rectal temperature of 3- to 6-month-old mice (open squares; $n=18$-6), and 6-weekold mice (filled triangles; $n=6$ ). $B$, Plasma glucose and insulin and rectal temperature of a second set of mice $(n=4)$. Data are means \pm SD. The asterisks indicate significant difference as follows: ${ }^{* *} p<0.01$. N.D., Nondetectable.

of a $36 \mathrm{kDa}$ catalytic subunit (C) tightly bound with the scaffolding $65 \mathrm{kDa}$ subunit termed PR65 or A. This core dimer associates with a variable regulatory $B$ subunit. To date, four $B$ subunit have been described: B, B', B", and B"' (Janssens and Goris, 2001). PP2A holoenzymes containing a PR55/B family member have been shown to bind and dephosphorylate tau with high efficiency (Goedert et al., 1992; Sontag et al., 1999). Of the four members of

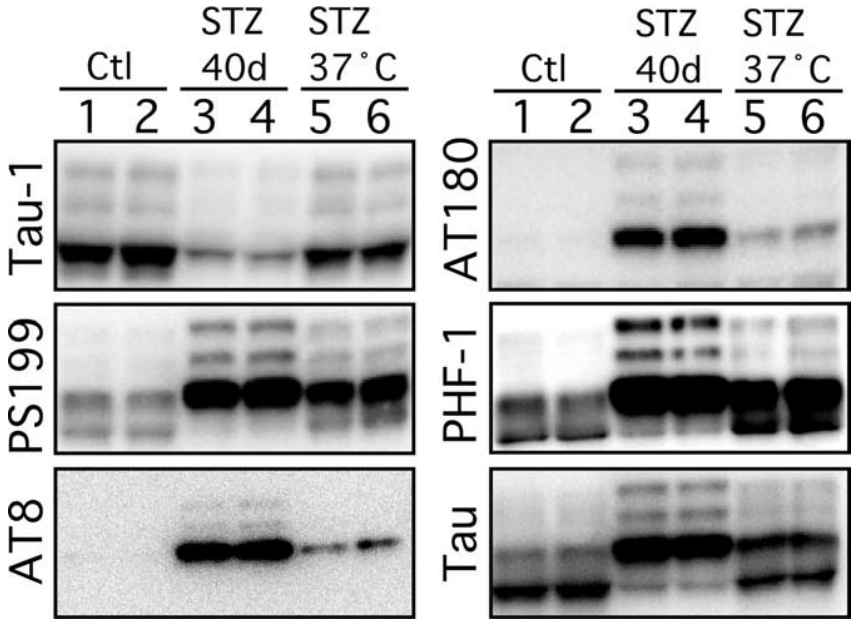

Figure 6. Effect of controlled temperature on tau phosphorylation during streptozotocininduced diabetes. Proteins from mouse brain hemispheres (hippocampus plus cortex) were separated by SDS-PAGE and identified with the antibodies listed on the left of each blot. Forty days of STZ treatment (lanes 3 and 4) induced a robust tau hyperphosphorylation at all the epitopes studied when compared with controls (lanes 1 and 2). Restoring normothermia by placing the animals $1 \mathrm{~h}$ at $37^{\circ} \mathrm{C}$ only partially rescued tau hyperphosphorylation (lanes 5 and 6 ). Each lane represents an individual mouse. Most of represented blots were overexposed to be able to visualize tau phosphorylation in lanes 5 and 6 .

the $\mathrm{B}$ family, only $\mathrm{B} \gamma$ and $\mathrm{B} \beta$ are brain specific (Strack et al., 1998 ), and only trimeric forms of $\mathrm{PP} 2 \mathrm{~A}$ containing the $\mathrm{B} \alpha$ or $\mathrm{B} \beta$ subunits associate with neural microtubules (Price et al., 1999). Expression of the A scaffolding subunit did not change during the treatment (Fig. 9Af,Bf); however, $\mathrm{B} \alpha$ was transiently upregulated $10 \mathrm{~d}$ after injection (Fig. $9 A d, B d$ ). Although $\mathrm{B} \beta$ total levels did not change during the experiment, the upper band increased, whereas the primary lower molecular weight band decreased 


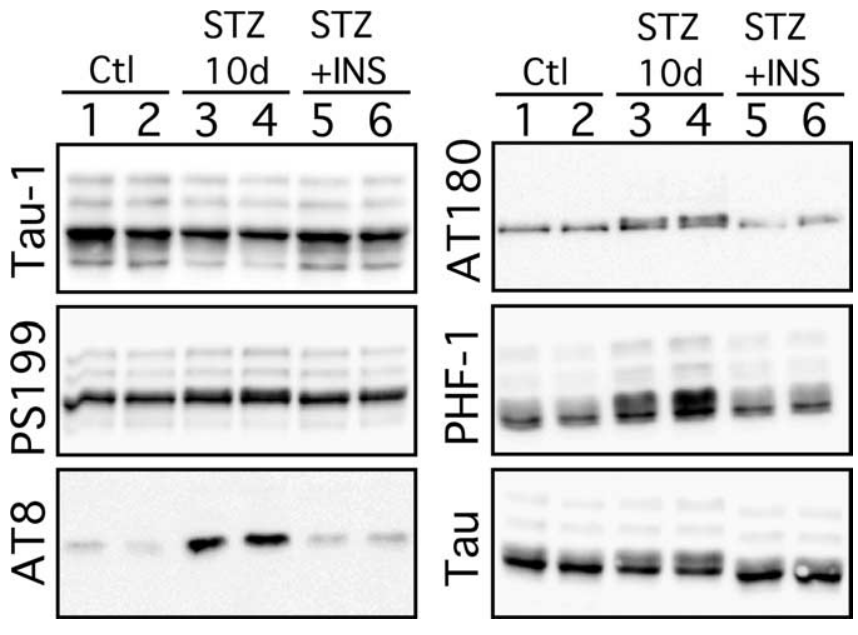

Figure 7. Effect of insulin on tau phosphorylation during streptozotocin-induced diabetes. Proteins from mouse brain hemispheres (hippocampus plus cortex) were separated by SDSPAGE and identified with the antibodies listed on the left of each blot. Ten days of STZ treatment (lanes 3 and 4) induced a slight hyperphosphorylation of tau at all the epitopes studied when compared with controls (lanes 1 and 2). Implantation of subcutaneous pumps delivering 0.75 $\mathrm{U} / \mathrm{d}$ of insulin rescued tau phosphorylation to control levels (lanes 5 and 6 ). Each lane represents an individual mouse. INS, Insulin.

(Fig. 9Ae,Be). Thus only changes in the $\mathrm{C}$ and $\mathrm{B} \beta$ subunits of PP2A inversely correlate with tau phosphorylation during hypoinsulinemia.

\section{PP2A is inhibited during STZ treatment}

We previously demonstrated that hypothermia induces tau hyperphosphorylation by direct inhibition of PP2A (Planel et al., 2004). Because tau hyperphosphorylation $40 \mathrm{~d}$ after STZ injection is mainly attributable to hypothermia (Fig. 5), we focused on examining the mechanism of tau hyperphosphorylation at $10 \mathrm{~d}$, when there is no overlapping inhibition of PP2A activity by temperature. To determine whether the changes in the subunits of PP2A were associated with the inhibition of the enzyme, we performed a phosphatase assay using brain lysates and endogenous brain tau as a substrate. Specifically, we monitored the dephosphorylation of the PHF-1 epitope at $10 \mathrm{~d}$ after STZ injection. We previously demonstrated that, in these conditions, PHF-1 dephosphorylation is mainly attributable to endogenous PP2A activity (Planel et al., 2007). Brain extracts from 10-d-injected mice (Fig. 10A) (decay rate constant, $3.87 \mathrm{~min} ; R^{2}=0.997$ ) showed a significant reduction $(p<0.0001)$ in tau dephosphorylation compared with controls (Fig. 10A) (decay rate constant, 6.48 min; $\left.R^{2}=0.992\right)$, suggesting that PP2A is inhibited during STZinduced diabetes. To verify this endogenous dephosphorylation assay, we performed the same experiment with a commercially available PP2A assay system, and included STZ-treated mice implanted with insulin pumps, as described above. This assay revealed a $\sim 15 \%$ decrease in brain PP2A activity during STZinduced diabetes, but no significant change in insulin-competent animals (Fig. $10 \mathrm{~B}$ ). Lastly, we performed an immunoprecipitation (IP) assay of PP2A in the samples at 10, 20, 30, and $40 \mathrm{~d}$ after STZ injection. This IP assay had more variability than the two previous ones, but revealed a $\sim 30 \%$ inhibition of PP2A after induction of diabetes (Fig. 10C). The differences between the two assays are probably attributable to the different protocols. No additional inhibition of PP2A at $40 \mathrm{~d}$ was detected by this assay because the inhibition of phosphatase by temperature at $40 \mathrm{~d}$ after STZ treatment is caused by a direct effect of hypothermia on enzyme activities in the brain, and is therefore not detectable by an assay performed at constant temperature for all the samples (Planel et al., 2004, 2007). Thus, PP2A inhibition occurs early during STZ treatment, is attributable to hypoinsulinemia, and might be responsible for the increased levels of hyperphosphorylated tau observed $10 \mathrm{~d}$ after injection.

\section{APP and A $\beta$ are not affected by STZ treatment}

Previous data have shown that diet-induced insulin resistance promotes $\mathrm{A} \beta_{1-40}$ and $\mathrm{A} \beta_{1-42}$ peptide generation in a transgenic mouse model of $\beta$-amyloidosis (Ho et al., 2004). In addition, other studies suggest that insulin can modulate $\mathrm{A} \beta$ levels (Gasparini et al., 2002; Hoyer, 2004), which is known to influence tau phosphorylation (Blurton-Jones and Laferla, 2006). We therefore examined the possibility of change in APP metabolism and $\mathrm{A} \beta$ levels in STZ-treated mice, because it could be a plausible mechanism for the mild tau hyperphosphorylation observed. No change was observed in either APP, APP C-terminal fragments, or $\mathrm{A} \beta$ levels after $10 \mathrm{~d}$ of hypoinsulinemia (Fig. $11 A-C$ ), suggesting no association between $A \beta$ and the mild and early tau hyperphosphorylation after STZ injection.

\section{Discussion}

We investigated the in vivo relationship between insulin dysfunction and tau phosphorylation. Our results indicate that STZinduced insulin deficiency rapidly leads to a biochemical and histochemical pattern of tau phosphorylation similar to that seen in early $\mathrm{AD}$, with hyperphosphorylation of tau at multiple epitopes seen in the neuropil and axonal tracks. Our data suggest that tau hyperphosphorylation during diabetes is likely a result of PP2A inhibition.

Hypothermia is a common outcome in both human (Neil et al., 1986; Scott et al., 1987) and experimental diabetes (Shalaby et al., 1989; Kilgour and Williams, 1996, 1998). In STZ-induced DM, the occurrence of hypothermia has generally been associated with numerous abnormalities such as decrease in nonshivering thermogenesis (Seydoux et al., 1983), lack of shivering (Kilgour and Williams, 1996), and the inability to use carbohydrates for heat production (Smith and Davidson, 1982). These abnormalities develop over time and, whereas at 10-30 d after STZ injection the animals were still able to maintain normothermia and had mild tau hyperphosphorylation, by $40 \mathrm{~d}$ they were fully hypothermic and had massive tau phosphorylation. This massive hyperphosphorylation was mostly, but not completely, rescued by returning the animals to normothermia, demonstrating that it is mainly attributable to hypothermia and not just correlative to it. However, insulin treatment of diabetic animals completely restored tau phosphorylation to control levels, demonstrating that the mild hyperphosphorylation was attributable to the lack of insulin. In light of our previous results demonstrating that hypothermia induces tau hyperphosphorylation that is completely reversible by normothermia (Planel et al., 2004, 2007), our data indicate that there are probably two distinct and overlapping tau hyperphosphorylation events during DM. One is mild, temperature independent, hypoinsulinemia dependent, and observed for the whole duration of diabetes. The other is massive and consequent to hypothermia and overlaps the first type in the later stage of STZ-induced DM. These results confirm and extend previous studies reporting tau hyperphosphorylation after STZ treatment in mice (Zhao et al., 2003; Clodfelder-Miller et al., 2006).

Our data show that insulin treatment totally prevented hyperphosphorylation, thus demonstrating that changes in tau phos- 


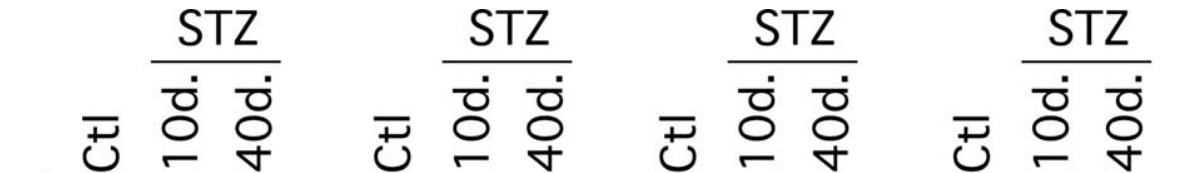

A. 123

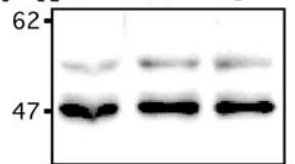

a. GSK-3 $\beta$ pY216

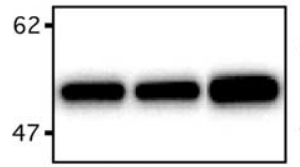

e. CaMKII

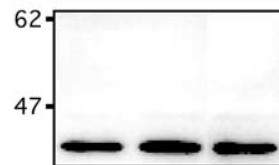

i. MAPK
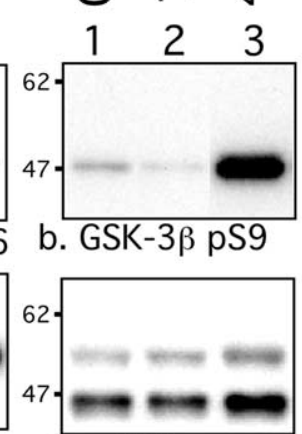

f. p-JNK

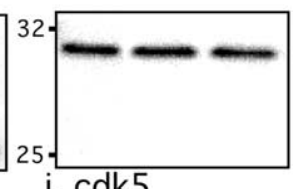

j. cdk5

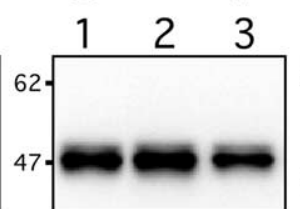

c. GSK-3 $\beta$

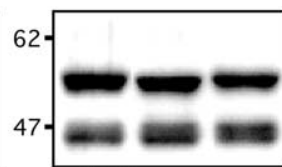

g. JNK

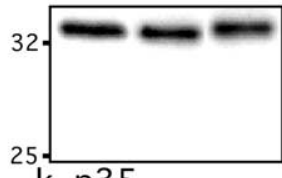

k. p35

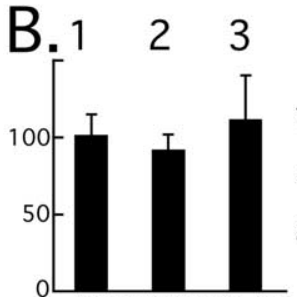

a. $\mathrm{pY} 216 / \mathrm{GSK}-3 \beta$
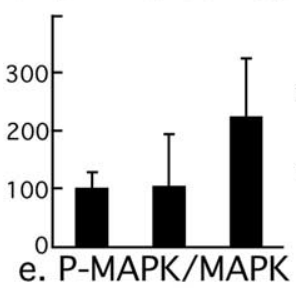

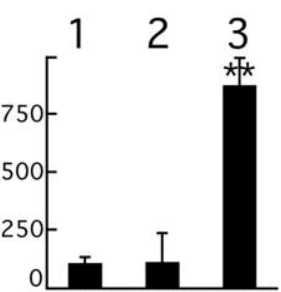

b. $\mathrm{pS} 9 / \mathrm{GSK}-3 \beta$

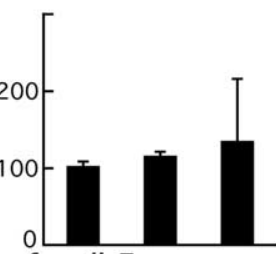

f. cdk5

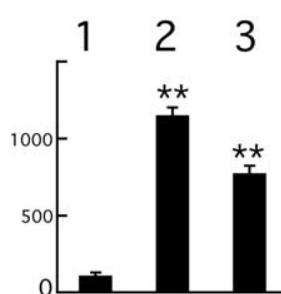

c. p-CaMKII/CaMKII

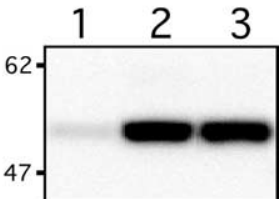

d. p-CaMKII

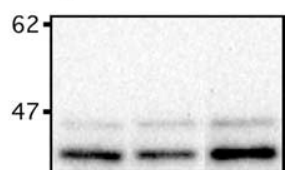

h. p-MAPK

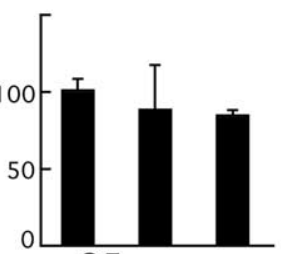

g. p35

Figure 8. Effect of streptozotocin on tau kinases activation. $\boldsymbol{A}$, Proteins from mouse brain hemispheres (hippocampus plus cortex) were separated by SDS-PAGE and identified with the antibodies indicated at the bottom of the boxes. For each antibody, one representative data of four for each condition (1, Ctl, control; 2, 10d., or 3, $40 \mathrm{~d}$., 10 or $40 \mathrm{~d}$ after STZ injection) are displayed in the top part of the boxes. Each lane represents an individual mouse. $\boldsymbol{B}$, The graphs show the quantification of the bands $(n=4)$. For graphs $\boldsymbol{a}-\boldsymbol{e}$, the level of phospho-kinase is normalized to the level of total kinase. For JNK $(\boldsymbol{f}, \boldsymbol{g}), \mathrm{p} 46$ (open columns) and p54 (filled columns) were quantified separately. The immunoreactivity is expressed as a percentage of the control treatment (100\%, first column). The numbers in the graphs indicate the percentage of the line with which they are aligned. Data are means $\pm S D$. The asterisks indicate significant differences as follows: ${ }^{*} p<0.05$ and ${ }^{* *} p<0.01$.

phorylation are attributable to hypoinsulinemia. STZ-induced DM leads to lower brain insulin content, and insulin has been shown to downregulate tau phosphorylation in neuronal cells (Hong and Lee, 1997; Lesort et al., 1999). Thus, it is possible that the early and mild tau hyperphosphorylation in STZ-treated mice is a consequence of reduced insulin signaling in the brain. This interpretation is further strengthened by observations of hyperphosphorylated tau in mice models of insulin dysfunction (Schubert et al., 2003, 2004; Schechter et al., 2005).

Our results suggest that inhibition of PP2A by low temperature is probably the cause of the late, hypothermia-induced hyperphosphorylation of tau, because we already demonstrated that hypothermia leads to direct inhibition of PP2A (Planel et al., 2004, 2007). The changes in PP2A subunits ( $C$ and $B \beta$ ) as early as
$10 \mathrm{~d}$ after treatment suggested an involvement of PP2A in the early hyperphosphorylation of tau, and indeed PP2A activity was inhibited during the early STZinduced insulin dysfunction. Although seemingly counterintuitive, the increase of the $\mathrm{C}$ catalytic subunit along with a decrease in activity could be explained by the potent autoregulatory mechanism that adjusts PP2A C levels according to PP2A activity, in which inhibition of PP2A leads to the accumulation of the $\mathrm{C}$ subunit, either in vitro or in vivo (Baharians and Schonthal, 1998; Planel et al., 2001). Alternatively, posttranslational modifications of PP2A C could have altered the affinity of the antibody used for detection. The meaning of the shift in $\mathrm{B} \beta$ banding pattern is less clear, but it is interesting to note that the $\mathrm{B} \beta$ subunit associates with neural microtubules (Price et al., 1999). It is therefore possible that posttranslational changes in $\mathrm{B} \beta$ could regulate PP $2 \mathrm{~A}$ activity toward tau associated with microtubules during insulin dysfunction. Additional studies are needed to address these possibilities. Our results do not exclude inhibition of other phosphatases during STZ treatment, but among all three phosphatases that were confirmed to be able to dephosphorylate tau, numerous evidence indicates that PP2A is likely to be the major tau phosphatase in vivo (Gong et al., 2000; Planel et al., 2001, 2004, 2007). Globally, our results indicate that there is probably two distinct, but overlapping mechanisms of tau hyperphosphorylation in STZtreated mice. One is early and temperature-independent and seems to be related to changes in the PP2A B $\beta$ regulatory subunit during insulin deficiency. The other is induced by the direct effect of hypothermia on PP2A activity and is observed only in the later stage of DM (Fig. 12).

It should be noted that in vivo tau hyperphosphorylation can be induced by basal kinases activity, although they are inhibited or not activated, simply by a shift in phosphorylation equilibrium as a result of phosphatase inhibition (Planel et al., 2001, 2007). In other words, inhibiting PP2A is like activating all the tau kinases together because PP2A dephosphorylates all the known tau epitopes, whereas each kinase is specific for only a set of given epitopes (Wang et al., 2007).

Inhibition of PP2A might not be the only factor contributing to tau hyperphosphorylation during DM. For example, diabetes can affect protein glycosylation (Williams et al., 1982), and glycosylation has been shown to modulate tau phosphorylation (Liu et al., 2004). Although PP2A inhibition is likely to be the main factor leading to hyperphosphorylation after STZ treatment, additional studies will be necessary to dissect out all the other contributing factors.

Many longitudinal population-based studies have detected 


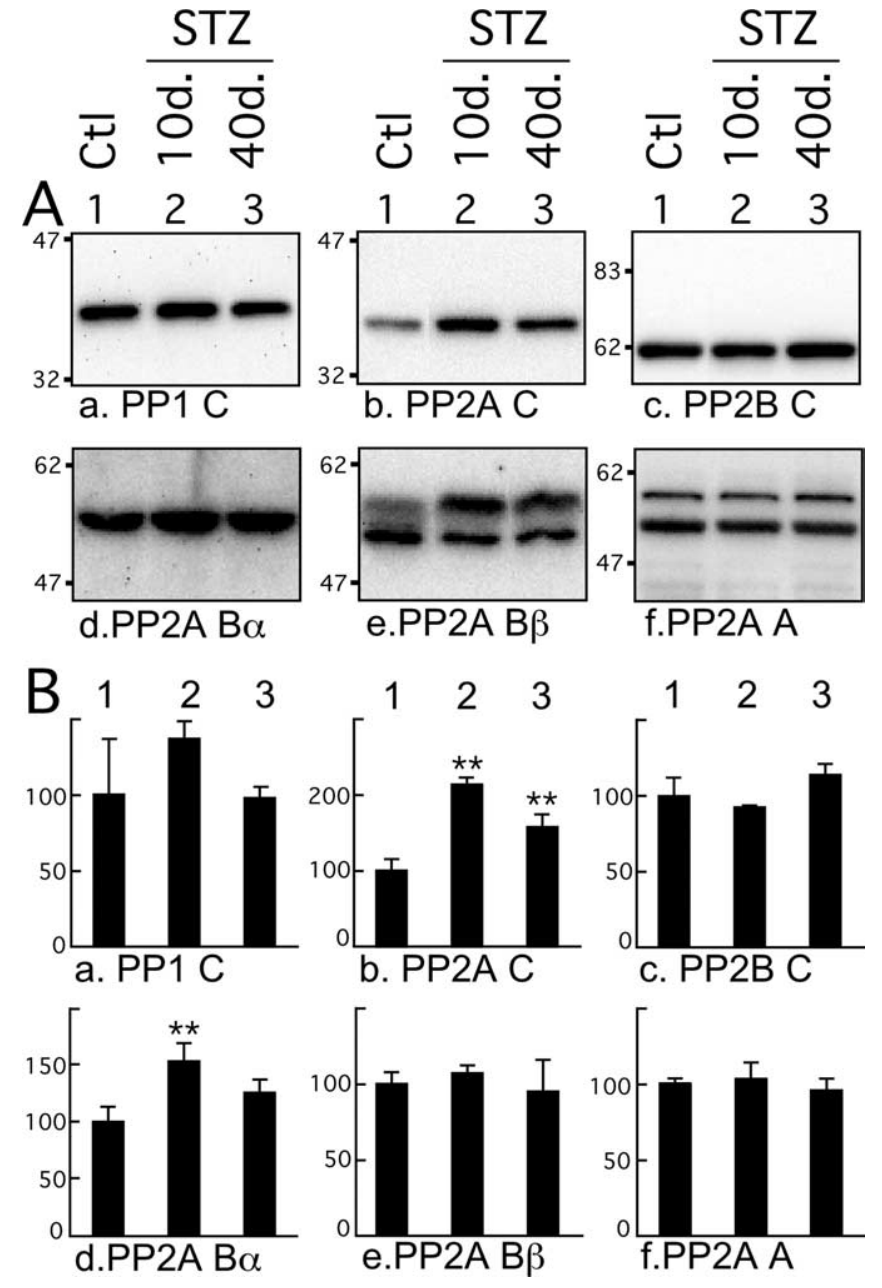

Figure 9. Effect of streptozotocin on phosphatases levels. $\boldsymbol{A}$, Proteins from mouse brain hemispheres (hippocampus plus cortex) were separated by SDS-PAGE and identified with the antibodies indicated at the bottom of the boxes. PP1C, PP2AC, and PP2B C detect the catalytic subunits of $P P 1, P P 2 A$, and $P P 2 B$, respectively. $P P 2 A B \alpha$ and $B \beta$ detect $B \alpha$ and $B \beta$ regulatory subunits of PP2A, and PP2A A detects anchoring subunits. For each antibody, one representative data of four for each condition (1, Ctl, control; 2, 10d., or 3, 40d., 10 or $40 \mathrm{~d}$ after STZ injection) are displayed in the top part of the boxes. Each lane represents an individual mouse. $\boldsymbol{B}$, The graphs show the quantification of the bands $(n=4)$. The immunoreactivity is expressed as a percentage of the control treatment (100\%, first column). The numbers in the graphs indicate the percentage of the line with which they are aligned. Data are means \pm SD. The asterisks indicate significant differences as follows: ${ }^{*} p<0.05$ and ${ }^{* *} p<0.01$.

higher $\mathrm{AD}$ incidence rates in type $2 \mathrm{DM}$ patients (Leibson et al., 1997; Ott et al., 1999; Peila et al., 2002; Arvanitakis et al., 2004; Luchsinger et al., 2005). Type 2 DM, the most common in adults and in the elderly, is preceded in most individuals by insulin resistance and hyperinsulinemia to maintain glucose homeostasis (Festa et al., 2006). Over time, the pancreas becomes unable to produce enough insulin to overcome the resistance; the $\beta$-cells burnout and insulin production decreases dramatically, causing full-blown diabetes (DeFronzo, 2004). Interestingly, at least two longitudinal studies found that diabetic patients who required treatment with insulin replacement, presumably those with the lowest pancreatic insulin production, had the highest risk of AD compared with persons using oral medications and those without diabetes (Ott et al., 1999; Luchsinger et al., 2001). Thus, although STZ-induced diabetes is not a model of early type 2 DM, it addresses mechanisms related to the low insulin levels that accompany type $2 \mathrm{DM}$ in the end of its natural history. Here, we dem-
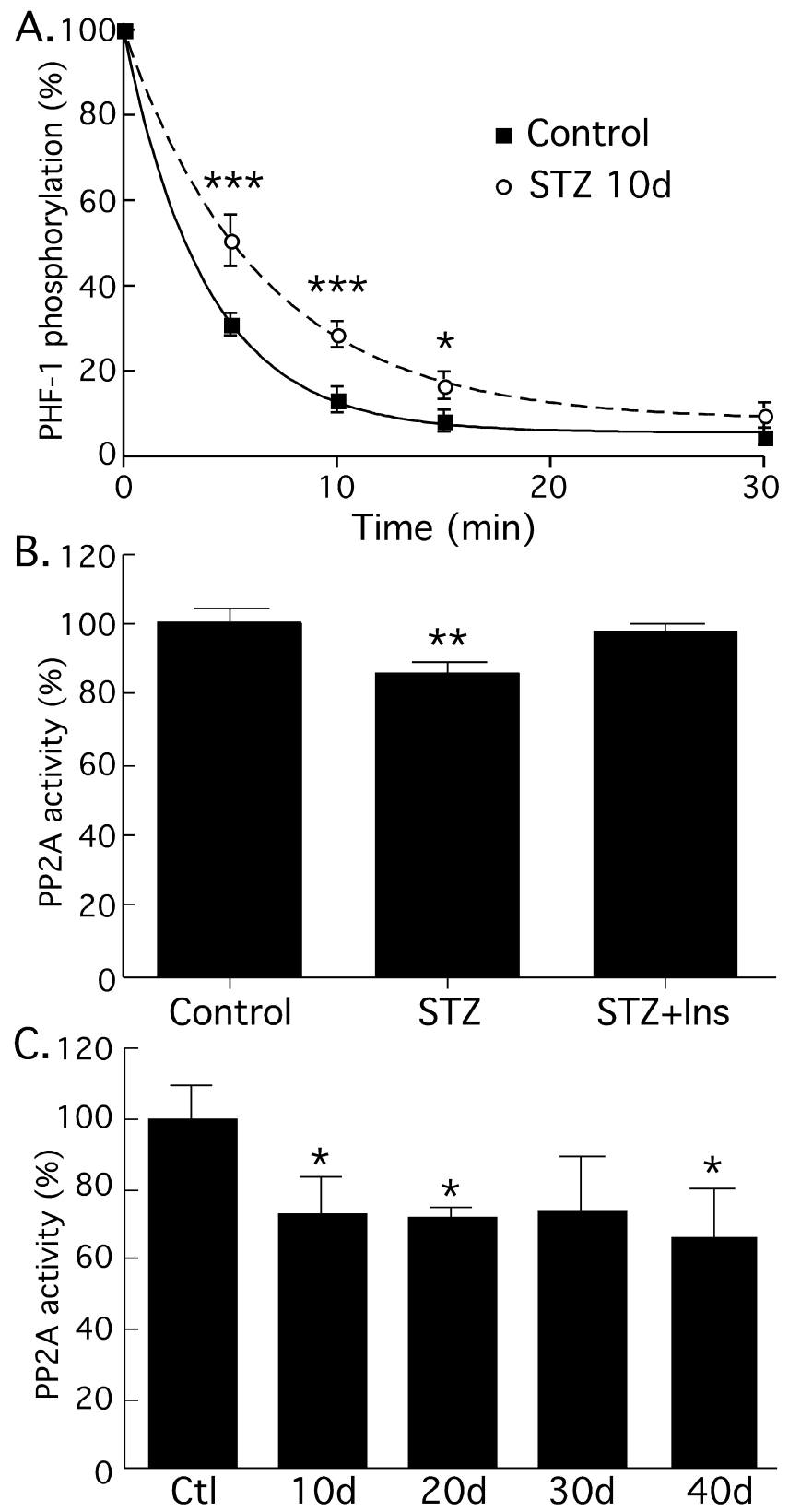

Figure 10. Effect of streptozotocin treatment on phosphatase activity. $\boldsymbol{A}$, Phosphatase activity was evaluated by endogenous tau dephosphorylation followed by Western blot analysis $(n=3)$. Tau from control brains (solid squares, solid line) was dephosphorylated faster than tau from animals treated with STZ after $10 \mathrm{~d}$ (solid circles, dotted line). $\boldsymbol{B}$, To confirm this result, PP2A activity was evaluated with the PP2A Assay System from Promega. Similarly to the endogenous assay, PP2A activity was inhibited in $10 \mathrm{~d}$ STZ-treated mice $(n=3)$. Implantation of subcutaneous pumps delivering $0.75 \mathrm{U} / \mathrm{d}$ insulin in STZ-treated mice restored PP2A activity to control levels. C, Immunoprecipitation assay of PP2A after STZ treatment. PP2A presented similar level of inhibition at 10,20,30, and $40 \mathrm{~d}$ after injection. Data are means \pm SD. The asterisks indicate significant differences as follows: ${ }^{*} p<0.05,{ }^{* *} p<0.01$, and ${ }^{* * *} p<0.001$.

onstrated that STZ-induced insulin dysfunction led to AD-like tau hyperphosphorylation induced by inhibition of PP2A. In AD, decreased PP2A expression (Vogelsberg-Ragaglia et al., 2001) along with upregulation of its inhibitors (Tanimukai et al., 2005), results in overall inhibition of its activity (Gong et al., 1993, 1995), which might be an important factor in the evolution of the pathology (Tian and Wang, 2002). Thus, during insulin dysfunction, inhibition of PP2A and the consequent tau hyperphospho- 


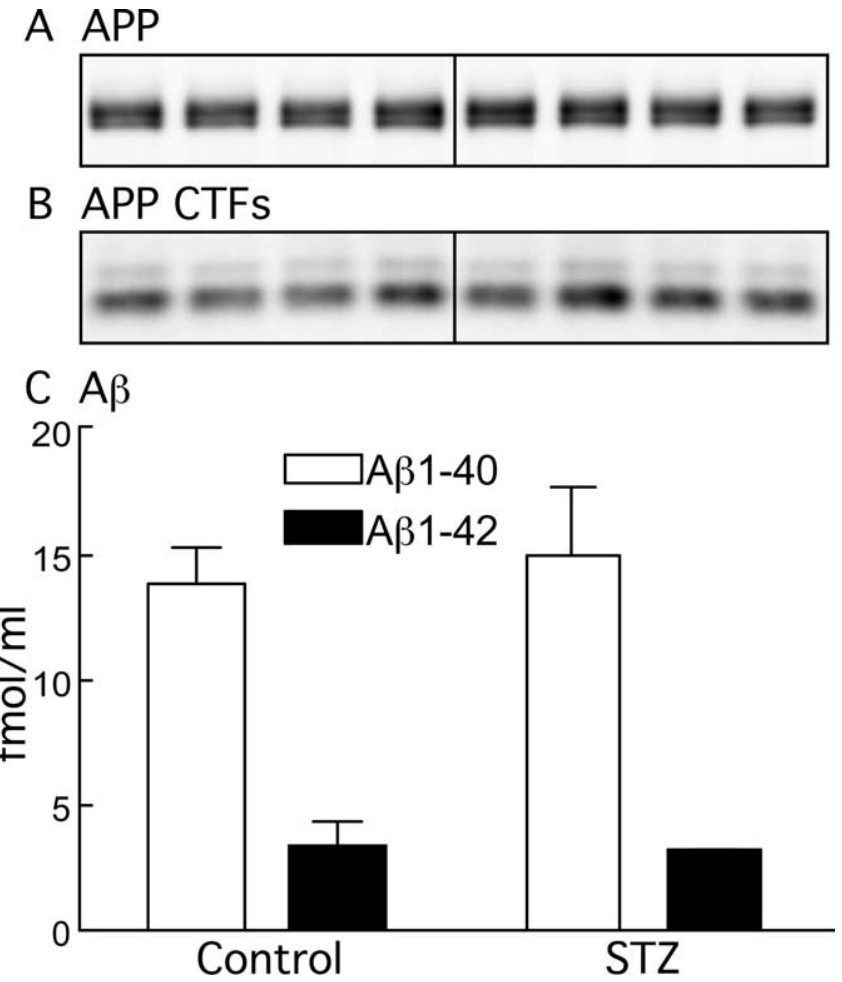

Figure 11. Effect of streptozotocin on APP metabolism. Proteins from mouse brain hemispheres (hippocampus plus cortex) of control and $10 \mathrm{~d}$ STZ-treated mice were separated by SDS-PAGE and identified with $C 1 / 6.1$ antibody, which recognize APP $(\boldsymbol{A})$ and $\mathrm{CTFs}(\boldsymbol{B})$. C shows the levels of $A \beta_{1-40}$ (open bars) and $A \beta_{1-42}$ (filled bars) for control and STZ $10 \mathrm{~d}$, as detected by ELISA $(n=4)$. Data are means \pm SD.

rylation might interact with biological or genetic susceptibilities to increase the vulnerability of the brain to insults associated with AD. PP2A inhibition may not be a direct consequence of insulin depletion; but the outcome of this (either directly or indirectly) is tau hyperphosphorylation that is potentially of significance for $\mathrm{AD}$, which is relevant regardless of the intermediate steps. It is unclear whether the high insulin levels that precede full-blown diabetes has a role in the relationship observed between diabetes and $\mathrm{AD}$, and this needs to be taken into account for future studies (Luchsinger and Mayeux, 2007).

In $\mathrm{AD}$, the hyperphosphorylation of tau by the deregulation of kinases and/or phosphatases has been proposed to lead to tau aggregation and prevent tau binding to MTs, thereby destabilizing the MT network (Alonso et al., 1994; Feinstein and Wilson, 2005; Mi and Johnson, 2006). Hyperphosphorylation of human tau induces MT disruption (Ebneth et al., 1999), as well as tau aggregation in vitro (Alonso et al., 2001; Sato et al., 2002). Here, despite sustained mild hyperphosphorylation of tau for $30 \mathrm{~d}$ and massive late hyperphosphorylation, we could not detect aggregated tau in mice, and tau binding to MTs was affected only at $40 \mathrm{~d}$ after STZ treatment. The differences in sequence and isoform composition between human and mouse tau (Janke et al., 1999), cannot explain the lack of tau aggregates in nontransgenic mice, because rodent tau can form PHFs as readily as human tau after being hyperphosphorylated in vitro (Chohan et al., 2005). Thus, absence of aggregates could be attributable to insufficient levels of total tau phosphorylation in the STZ model, or to insufficient levels of phosphorylation at epitopes promoting aggregation. What remain to be determined is how much impact diabetes can have on tau pathogenesis. Examination of the development

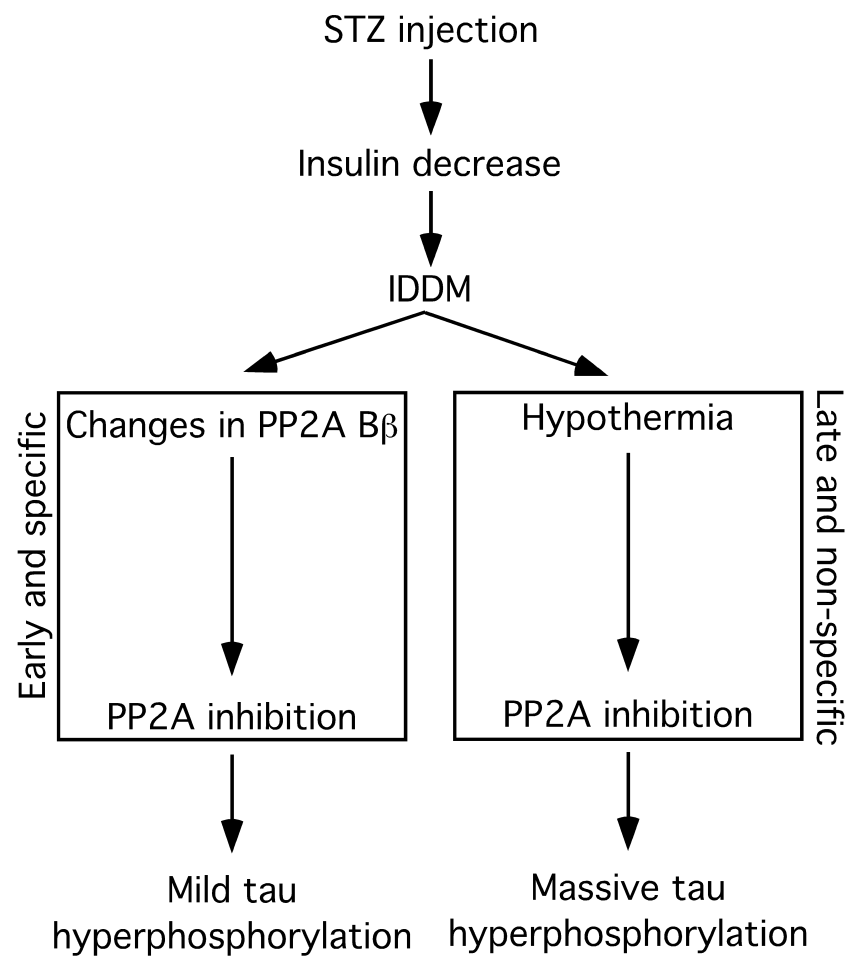

Figure 12. Putative mechanism of tau hyperphosphorylation during insulin dysfunction. Injection of STZ induces immediate decrease of pancreatic insulin secretion and results in insulin-dependent diabetes mellitus. During the early phase of DM, when the adult mice are still normothermic, PP2A is inhibited, presumably through changes in the $\mathrm{B} \beta$ regulatory subunit, which leads to a mild hyperphosphorylation of tau specific to insulin deficiency, as demonstrated in Figures 7 and 10. In the later phase of DM, deficits in peripheral glucose/energy metabolism lead to hypothermia. This leads to a direct inhibition of PP2A activity by low temperatures, resulting in massive hyperphosphorylation of tau not specific to hypoinsulinemia. The early and mild tau hyperphosphorylation is still present at this stage, but is masked by the effects of hypothermia, as demonstrated in Figure 6.

of tau pathology in diabetic transgenic animal models expressing mutant tau that assemble at considerably lower levels of phosphorylation than normal tau (Alonso et al., 2004), may be able to address this question.

\section{References}

Alonso AC, Zaidi T, Grundke-Iqbal I, Iqbal K (1994) Role of abnormally phosphorylated tau in the breakdown of microtubules in Alzheimer disease. Proc Natl Acad Sci USA 91:5562-5566.

Alonso AC, Zaidi T, Novak M, Grundke-Iqbal I, Iqbal K (2001) Hyperphosphorylation induces self-assembly of tau into tangles of paired helical filaments/straight filaments. Proc Natl Acad Sci USA 98:6923-6928.

Alonso AC, Mederlyova A, Novak M, Grundke-Iqbal I, Iqbal K (2004) Promotion of hyperphosphorylation by frontotemporal dementia tau mutations. J Biol Chem 279:34873-34881.

Andorfer C, Kress Y, Espinoza M, de Silva R, Tucker KL, Barde YA, Duff K, Davies P (2003) Hyperphosphorylation and aggregation of tau in mice expressing normal human tau isoforms. J Neurochem 86:582-590.

Arvanitakis Z, Wilson RS, Bienias JL, Evans DA, Bennett DA (2004) Diabetes mellitus and risk of Alzheimer disease and decline in cognitive function. Arch Neurol 61:661-666.

Avila J, Lucas JJ, Perez M, Hernandez F (2004) Role of tau protein in both physiological and pathological conditions. Physiol Rev 84:361-384.

Baharians Z, Schonthal AH (1998) Autoregulation of protein phosphatase type 2A expression. J Biol Chem 273:19019-19024.

Bancher C, Brunner C, Lassmann H, Budka H, Jellinger K, Wiche G, Seitelberger F, Grundke-Iqbal I, Iqbal K, Wisniewski HM (1989) Accumulation of abnormally phosphorylated tau precedes the formation of neurofibrillary tangles in Alzheimer's disease. Brain Res 477:90-99. 
Bhardwaj SK, Kaur G (1999) Effect of diabetes on calcium/calmodulin dependent protein kinase-II from rat brain. Neurochem Int 35:329-335.

Biessels GJ, Staekenborg S, Brunner E, Brayne C, Scheltens P (2006) Risk of dementia in diabetes mellitus: a systematic review. Lancet Neurol $5: 64-74$.

Blurton-Jones M, Laferla FM (2006) Pathways by which Abeta facilitates tau pathology. Curr Alzheimer Res 3:437-448.

Braak E, Braak H, Mandelkow EM (1994) A sequence of cytoskeleton changes related to the formation of neurofibrillary tangles and neuropil threads. Acta Neuropathol 87:554-567.

Burns M, Gaynor K, Olm V, Mercken M, LaFrancois J, Wang L, Mathews PM, Noble W, Matsuoka Y, Duff K (2003) Presenilin redistribution associated with aberrant cholesterol transport enhances $\beta$-amyloid production in vivo. J Neurosci 23:5645-5649.

Bussiere T, Hof PR, Mailliot C, Brown CD, Caillet-Boudin ML, Perl DP, Buee L, Delacourte A (1999) Phosphorylated serine422 on tau proteins is a pathological epitope found in several diseases with neurofibrillary degeneration. Acta Neuropathol (Berl) 97:221-230.

Chohan MO, Haque N, Alonso A, El-Akkad E, Grundke-Iqbal I, Grover A, Iqbal K (2005) Hyperphosphorylation-induced self assembly of murine tau: a comparison with human tau. J Neural Transm 112:1035-1047.

Clodfelder-Miller BJ, Zmijewska AA, Johnson GV, Jope RS (2006) Tau is hyperphosphorylated at multiple sites in mouse brain in vivo after streptozotocin-induced insulin deficiency. Diabetes 55:3320-3325.

Cohen P (1989) The structure and regulation of protein phosphatases. Annu Rev Biochem 58:453-508.

Cole GM, Frautschy SA (2007) The role of insulin and neurotrophic factor signaling in brain aging and Alzheimer's Disease. Exp Gerontol 42:10-21.

Craft S, Peskind E, Schwartz MW, Schellenberg GD, Raskind M, Porte Jr D (1998) Cerebrospinal fluid and plasma insulin levels in Alzheimer's disease: relationship to severity of dementia and apolipoprotein E genotype. Neurology 50:164-168.

Cuthbertson RA, Koulmanda M, Mandel TE (1988) Detrimental effect of chronic diabetes on growth and function of fetal islet isografts in mice. Transplantation 46:650-654.

DeFronzo RA (2004) Pathogenesis of type 2 diabetes mellitus. Med Clin North Am 88:787-835, ix.

Ebneth A, Drewes G, Mandelkow EM, Mandelkow E (1999) Phosphorylation of MAP2c and MAP4 by MARK kinases leads to the destabilization of microtubules in cells. Cell Motil Cytoskeleton 44:209-224.

Feinstein SC, Wilson L (2005) Inability of tau to properly regulate neuronal microtubule dynamics: a loss-of-function mechanism by which tau might mediate neuronal cell death. Biochim Biophys Acta 1739:268-279.

Festa A, Williams K, D’Agostino Jr R, Wagenknecht LE, Haffner SM (2006) The natural course of beta-cell function in nondiabetic and diabetic individuals: the Insulin Resistance Atherosclerosis Study. Diabetes 55:1114-1120.

Figlewicz DP, Dorsa D, Ikeda H, Stein LJ, Baskin D, Woods SC (1983) Brain insulin binding and contents are altered by streptozotocin treatment in rats. Diabetes 32:134a.

Finch CE, Cohen DM (1997) Aging, metabolism, and Alzheimer disease: review and hypotheses. Exp Neurol 143:82-102.

Frank HJ, Pardridge WM, Jankovic-Vokes T, Vinters HV, Morris WL (1986) Insulin binding to the blood-brain barrier in the streptozotocin diabetic rat. J Neurochem 47:405-411.

Frolich L, Blum-Degen D, Riederer P, Hoyer S (1999) A disturbance in the neuronal insulin receptor signal transduction in sporadic Alzheimer's disease. Ann NY Acad Sci 893:290-293.

Gasparini L, Netzer WJ, Greengard P, Xu H (2002) Does insulin dysfunction play a role in Alzheimer's disease? Trends Pharmacol Sci 23:288-293.

Glenner GG, Wong CW (1984) Alzheimer's disease: initial report of the purification and characterization of a novel cerebrovascular amyloid protein. Biochem Biophys Res Commun 120:885-890.

Goedert M, Cohen ES, Jakes R, Cohen P (1992) p42 MAP kinase phosphorylation sites in microtubule-associated protein tau are dephosphorylated by protein phosphatase $2 \mathrm{~A} 1$. Implications for Alzheimer's disease. FEBS Lett [Erratum (1992) 313:203] 312:95-99.

Goedert M, Jakes R, Crowther RA, Cohen P, Vanmechelen E, Vandermeeren M, Cras P (1994) Epitope mapping of monoclonal antibodies to the paired helical filaments of Alzheimer's disease: identification of phosphorylation sites in tau protein. Biochem J 301:871-877.

Goedert M, Jakes R, Vanmechelen E (1995) Monoclonal antibody AT8 recognises tau protein phosphorylated at both serine 202 and threonine 205. Neurosci Lett 189:167-169.

Gong CX, Singh TJ, Grundke-Iqbal I, Iqbal K (1993) Phosphoprotein phosphatase activities in Alzheimer disease brain. J Neurochem 61:921-927.

Gong CX, Grundke-Iqbal I, Damuni Z, Iqbal K (1994) Dephosphorylation of microtubule-associated protein tau by protein phosphatase- 1 and $-2 \mathrm{C}$ and its implication in Alzheimer disease. FEBS Lett 341:94-98.

Gong CX, Shaikh S, Wang JZ, Zaidi T, Grundke-Iqbal I, Iqbal K (1995) Phosphatase activity toward abnormally phosphorylated tau: decrease in Alzheimer disease brain. J Neurochem 65:732-738.

Gong CX, Lidsky T, Wegiel J, Zuck L, Grundke-Iqbal I, Iqbal K (2000) Phosphorylation of microtubule-associated protein tau is regulated by protein phosphatase $2 \mathrm{~A}$ in mammalian brain. Implications for neurofibrillary degeneration in Alzheimer's disease. J Biol Chem 275:5535-5544.

Greenberg SG, Davies P (1990) A preparation of Alzheimer paired helical filaments that displays distinct tau proteins by polyacrylamide gel electrophoresis. Proc Natl Acad Sci USA 87:5827-5831.

Grunblatt E, Salkovic-Petrisic M, Osmanovic J, Riederer P, Hoyer S (2007) Brain insulin system dysfunction in streptozotocin intracerebroventricularly treated rats generates hyperphosphorylated tau protein. J Neurochem 101:757-770.

Grundke-Iqbal I, Iqbal K, Tung YC, Quinlan M, Wisniewski HM, Binder LI (1986) Abnormal phosphorylation of the microtubule-associated protein tau (tau) in Alzheimer cytoskeletal pathology. Proc Natl Acad Sci USA 83:4913-4917.

Harman D (2002) Alzheimer's disease: role of aging in pathogenesis. Ann NY Acad Sci 959:384-395; discussion 463-465.

Hasegawa M, Jakes R, Crowther RA, Lee VM, Ihara Y, Goedert M (1996) Characterization of $\mathrm{mAb}$ AP422, a novel phosphorylation-dependent monoclonal antibody against tau protein. FEBS Lett 384:25-30.

Heininger K (2000) A unifying hypothesis of Alzheimer's disease. IV. Causation and sequence of events. Rev Neurosci 11:213-328.

Ho L, Qin W, Pompl PN, Xiang Z, Wang J, Zhao Z, Peng Y, Cambareri G, Rocher A, Mobbs CV, Hof PR, Pasinetti GM (2004) Diet-induced insulin resistance promotes amyloidosis in a transgenic mouse model of Alzheimer's disease. FASEB J 18:902-904.

Hong M, Lee VM (1997) Insulin and insulin-like growth factor-1 regulate tau phosphorylation in cultured human neurons. J Biol Chem 272:19547-19553.

Howarth FC, Jacobson M, Naseer O, Adeghate E (2005) Short-term effects of streptozotocin-induced diabetes on the electrocardiogram, physical activity and body temperature in rats. Exp Physiol 90:237-245.

Hoyer S (2000) Brain glucose and energy metabolism abnormalities in sporadic Alzheimer disease. Causes and consequences: an update. Exp Gerontol 35:1363-1372.

Hoyer S (2002) The aging brain. Changes in the neuronal insulin/insulin receptor signal transduction cascade trigger late-onset sporadic Alzheimer disease (SAD). A mini-review. J Neural Transm 109:991-1002.

Hoyer S (2004) Glucose metabolism and insulin receptor signal transduction in Alzheimer disease. Eur J Pharmacol 490:115-125.

Ito M, Kondo Y, Nakatani A, Naruse A (1999) New model of progressive non-insulin-dependent diabetes mellitus in mice induced by streptozotocin. Biol Pharm Bull 22:988-989.

Itoh N, Arai H, Urakami K, Ishiguro K, Ohno H, Hampel H, Buerger K, Wiltfang J, Otto M, Kretzschmar H, Moeller HJ, Imagawa M, Kohno H, Nakashima K, Kuzuhara S, Sasaki H, Imahori K (2001) Large-scale, multicenter study of cerebrospinal fluid tau protein phosphorylated at serine 199 for the antemortem diagnosis of Alzheimer's disease. Ann Neurol 50:150-156.

Janke C, Beck M, Stahl T, Holzer M, Brauer K, Bigl V, Arendt T (1999) Phylogenetic diversity of the expression of the microtubule-associated protein tau: implications for neurodegenerative disorders. Brain Res Mol Brain Res 68:119-128.

Janssens V, Goris J (2001) Protein phosphatase 2A: a highly regulated family of serine/threonine phosphatases implicated in cell growth and signalling. Biochem J 353:417-439.

Kilgour RD, Williams PA (1996) Effects of diabetes and food deprivation on shivering activity during progressive hypothermia in the rat. Comp Biochem Physiol A Physiol 114:159-165.

Kilgour RD, Williams PA (1998) Diabetes affects blood pressure and heart rate responses during acute hypothermia. Acta Physiol Scand 162:27-32. 
Lamberts SW, van den Beld AW, van der Lely AJ (1997) The endocrinology of aging. Science 278:419-424.

Leibson CL, Rocca WA, Hanson VA, Cha R, Kokmen E, O’Brien PC, Palumbo PJ (1997) Risk of dementia among persons with diabetes mellitus: a population-based cohort study. Am J Epidemiol 145:301-308.

Lesort M, Johnson GV (2000) Insulin-like growth factor-1 and insulin mediate transient site-selective increases in tau phosphorylation in primary cortical neurons. Neuroscience 99:305-316.

Lesort M, Jope RS, Johnson GV (1999) Insulin transiently increases tau phosphorylation: involvement of glycogen synthase kinase-3beta and Fyn tyrosine kinase. J Neurochem 72:576-584.

Lester-Coll N, Rivera EJ, Soscia SJ, Doiron K, Wands JR, de la Monte SM (2006) Intracerebral streptozotocin model of type 3 diabetes: relevance to sporadic Alzheimer's disease. J Alzheimers Dis 9:13-33.

Litersky JM, Johnson GV, Jakes R, Goedert M, Lee M, Seubert P (1996) Tau protein is phosphorylated by cyclic AMP-dependent protein kinase and calcium/calmodulin-dependent protein kinase II within its microtubulebinding domains at Ser-262 and Ser-356. Biochem J 316:655-660.

Liu F, Iqbal K, Grundke-Iqbal I, Hart GW, Gong CX (2004) $O$-GlcNAcylation regulates phosphorylation of tau: a mechanism involved in Alzheimer's disease. Proc Natl Acad Sci USA 101:10804-10809.

Luchsinger JA, Mayeux R (2007) Adiposity and Alzheimer's disease. Curr Alzheimer Res 4:127-134.

Luchsinger JA, Tang MX, Stern Y, Shea S, Mayeux R (2001) Diabetes mellitus and risk of Alzheimer's disease and dementia with stroke in a multiethnic cohort. Am J Epidemiol 154:635-641.

Luchsinger JA, Reitz C, Honig LS, Tang MX, Shea S, Mayeux R (2005) Aggregation of vascular risk factors and risk of incident Alzheimer disease. Neurology 65:545-551.

Maas T, Eidenmuller J, Brandt R (2000) Interaction of tau with the neural membrane cortex is regulated by phosphorylation at sites that are modified in paired helical filaments. J Biol Chem 275:15733-15740.

Maccioni RB, Otth C, Concha II, Munoz JP (2001) The protein kinase Cdk5. Structural aspects, roles in neurogenesis and involvement in Alzheimer's pathology. Eur J Biochem 268:1518-1527.

Mathews PM, Jiang Y, Schmidt SD, Grbovic OM, Mercken M, Nixon RA (2002) Calpain activity regulates the cell surface distribution of amyloid precursor protein. Inhibition of clapains enhances endosomal generation of beta-cleaved C-terminal APP fragments. J Biol Chem 277:36415-36424.

Matsuo ES, Shin RW, Billingsley ML, Van deVoorde A, O'Connor M, Trojanowski JQ, Lee VM (1994) Biopsy-derived adult human brain tau is phosphorylated at many of the same sites as Alzheimer's disease paired helical filament tau. Neuron 13:989-1002.

Maurage CA, Sergeant N, Ruchoux MM, Hauw JJ, Delacourte A (2003) Phosphorylated serine 199 of microtubule-associated protein tau is a neuronal epitope abundantly expressed in youth and an early marker of tau pathology. Acta Neuropathol (Berl) 105:89-97.

Meier-Ruge W, Bertoni-Freddari C (1996) The significance of glucose turnover in the brain in the pathogenetic mechanisms of Alzheimer's disease. Rev Neurosci 7:1-19.

Mi K, Johnson GV (2006) The role of tau phosphorylation in the pathogenesis of Alzheimer's disease. Curr Alzheimer Res 3:449-463.

Mosconi L (2005) Brain glucose metabolism in the early and specific diagnosis of Alzheimer's disease. FDG-PET studies in MCI and AD. Eur J Nucl Med Mol Imaging 32:486-510.

Neil HA, Dawson JA, Baker JE (1986) Risk of hypothermia in elderly patients with diabetes. Br Med J (Clin Res Ed) 293:416-418.

Noble W, Olm V, Takata K, Casey E, Mary O, Meyerson J, Gaynor K, LaFrancois J, Wang L, Kondo T, Davies P, Burns M, Veeranna, Nixon R, Dickson D, Matsuoka Y, Ahlijanian M, Lau LF, Duff K (2003) Cdk5 is a key factor in tau aggregation and tangle formation in vivo. Neuron 38:555-565.

Noble W, Planel E, Zehr C, Olm V, Meyerson J, Suleman F, Gaynor K, Wang L, LaFrancois J, Feinstein B, Burns M, Krishnamurthy P, Wen Y, Bhat R, Lewis J, Dickson D, Duff K (2005) Inhibition of glycogen synthase kinase-3 by lithium correlates with reduced tauopathy and degeneration in vivo. Proc Natl Acad Sci USA 102:6990-6995.

O’Farrell PH (1975) High resolution two-dimensional electrophoresis of proteins. J Biol Chem 250:4007-4021.

Ott A, Stolk RP, van Harskamp F, Pols HA, Hofman A, Breteler MM (1999) Diabetes mellitus and the risk of dementia: The Rotterdam Study. Neurology 53:1937-1942.
Pacold ST, Blackard WG (1979) Central nervous system insulin receptors in normal and diabetic rats. Endocrinology 105:1452-1457.

Peila R, Rodriguez BL, Launer LJ (2002) Type 2 diabetes, APOE gene, and the risk for dementia and related pathologies: The Honolulu-Asia Aging Study. Diabetes 51:1256-1262.

Pezzino V, Costantino A, Russo P, Gullo D, Papa V (1996) Insulin receptor content in tissues of normal and diabetic rats measured by radioimmunoassay. J Endocrinol Invest 19:593-597.

Planel E, Yasutake K, Fujita SC, Ishiguro K (2001) Inhibition of protein phosphatase 2A overrides Tau protein kinase I/glycogen synthase kinase 3beta and Cyclin-dependant kinase 5 inhibition and results in tau hyperphosphorylation in the hippocampus of starved mouse. J Biol Chem 276:34298-34306.

Planel E, Sun X, Takashima A (2002) Role of GSK-3 beta in Alzheimer's disease pathology. Drug Development Res 56:491-510.

Planel E, Miyasaka T, Launey T, Chui DH, Tanemura K, Sato S, Murayama O, Ishiguro K, Tatebayashi Y, Takashima A (2004) Alterations in glucose metabolism induce hypothermia leading to tau hyperphosphorylation through differential inhibition of kinase and phosphatase activities: implications for Alzheimer's disease. J Neurosci 24:2401-2411.

Planel E, Richter KEG, Nolan CE, Finley JE, Liu L, Wen Y, Krishnamurthy P, Herman M, Wang L, Schachter JB, Nelson RB, Lau L-F, Duff KE (2007) Anesthesia leads to tau hyperphosphorylation through inhibition of phosphatase activity by hypothermia. J Neurosci 27:3090-3097.

Price NE, Wadzinski B, Mumby MC (1999) An anchoring factor targets protein phosphatase $2 \mathrm{~A}$ to brain microtubules. Brain Res Mol Brain Res 73:68-77.

Rivera EJ, Goldin A, Fulmer N, Tavares R, Wands JR, de la Monte SM (2005) Insulin and insulin-like growth factor expression and function deteriorate with progression of Alzheimer's disease: link to brain reductions in acetylcholine. J Alzheimers Dis 8:247-268.

Salehi A, Swaab DF (1999) Diminished neuronal metabolic activity in Alzheimer's disease. Review article. J Neural Transm 106:955-986.

Sato S, Tatebayashi Y, Akagi T, Chui DH, Murayama M, Miyasaka T, Planel E, Tanemura K, Sun X, Hashikawa T, Yoshioka K, Ishiguro K, Takashima A (2002) Aberrant tau phosphorylation by glycogen synthase kinase-3beta and JNK3 induces oligomeric tau fibrils in COS-7 cells. J Biol Chem 277:42060-42065.

Schechter R, Beju D, Miller KE (2005) The effect of insulin deficiency on tau and neurofilament in the insulin knockout mouse. Biochem Biophys Res Commun 334:979-986.

Schmidt SD, Nixon RA, Mathews PM (2005) ELISA method for measurement of amyloid-beta levels. Methods Mol Biol 299:279-297.

Schnedl WJ, Ferber S, Johnson JH, Newgard CB (1994) STZ transport and cytotoxicity. Specific enhancement in GLUT2-expressing cells. Diabetes 43:1326-1333.

Schubert M, Brazil DP, Burks DJ, Kushner JA, Ye J, Flint CL, Farhang-Fallah J, Dikkes P, Warot XM, Rio C, Corfas G, White MF (2003) Insulin receptor substrate-2 deficiency impairs brain growth and promotes tau phosphorylation. J Neurosci 23:7084-7092.

Schubert M, Gautam D, Surjo D, Ueki K, Baudler S, Schubert D, Kondo T, Alber J, Galldiks N, Kustermann E, Arndt S, Jacobs AH, Krone W, Kahn CR, Bruning JC (2004) Role for neuronal insulin resistance in neurodegenerative diseases. Proc Natl Acad Sci USA 101:3100-3105.

Scott AR, Bennett T, Macdonald IA (1987) Diabetes mellitus and thermoregulation. Can J Physiol Pharmacol 65:1365-1376.

Sechi LA, Griffin CA, Grady EF, Grunfeld C, Kalinyak JE, Schambelan M (1992) Tissue-specific regulation of insulin receptor mRNA levels in rats with STZ-induced diabetes mellitus. Diabetes 41:1113-1118.

Seydoux J, Chinet A, Schneider-Picard G, Bas S, Imesch E, AssimacopoulosJeannet F, Giacobino JP, Girardier L (1983) Brown adipose tissue metabolism in streptozotocin-diabetic rats. Endocrinology 113:604-610.

Shalaby TH, Yousef MK, Dupre RK (1989) Thermoregulatory responses of diabetic rats. Comp Biochem Physiol A 94:153-157.

Simpson IA, Appel NM, Hokari M, Oki J, Holman GD, Maher F, KoehlerStec EM, Vannucci SJ, Smith QR (1999) Blood-brain barrier glucose transporter: effects of hypo- and hyperglycemia revisited. J Neurochem 72:238-247.

Sironi JJ, Yen SH, Gondal JA, Wu Q, Grundke-Iqbal I, Iqbal K (1998) Ser262 in human recombinant tau protein is a markedly more favorable site for phosphorylation by CaMKII than PKA or PhK. FEBS Lett 436:471-475. 
Smith OL, Davidson SB (1982) Shivering thermogenesis and glucose uptake by muscles of normal or diabetic rats. Am J Physiol 242:R109-R115.

Sontag E, Nunbhakdi-Craig V, Lee G, Brandt R, Kamibayashi C, Kuret J, White III CL, Mumby MC, Bloom GS (1999) Molecular interactions among protein phosphatase $2 \mathrm{~A}$, tau, and microtubules. Implications for the regulation of tau phosphorylation and the development of tauopathies. J Biol Chem 274:25490-25498.

Strack S, Zaucha JA, Ebner FF, Colbran RJ, Wadzinski BE (1998) Brain protein phosphatase 2A: developmental regulation and distinct cellular and subcellular localization by B subunits. J Comp Neurol 392:515-527.

Su JH, Cummings BJ, Cotman CW (1993) Identification and distribution of axonal dystrophic neurites in Alzheimer's disease. Brain Res 625:228-237.

Su JH, Cummings BJ, Cotman CW (1994) Early phosphorylation of tau in Alzheimer's disease occurs at Ser-202 and is preferentially located within neurites. NeuroReport 5:2358-2362.

Szendrei GI, Lee VM, Otvos Jr L (1993) Recognition of the minimal epitope of monoclonal antibody Tau-1 depends upon the presence of a phosphate group but not its location. J Neurosci Res 34:243-249.

Tanimukai H, Grundke-Iqbal I, Iqbal K (2005) Up-regulation of inhibitors of protein phosphatase-2A in Alzheimer's disease. Am J Pathol 166:1761-1771.

Tian Q, Wang J (2002) Role of serine/threonine protein phosphatase in Alzheimer's disease. Neurosignals 11:262-269.

Tjalve H (1983) Streptozotocin: distribution, metabolism and mechanisms of action. Uppsala J Med Sci Suppl 39:145-157.
Trojanowski JQ, Lee VM (1994) Paired helical filament tau in Alzheimer's disease. The kinase connection. Am J Pathol 144:449-453.

Vogelsberg-Ragaglia V, Schuck T, Trojanowski JQ, Lee VM (2001) PP2A mRNA expression is quantitatively decreased in Alzheimer's disease hippocampus. Exp Neurol 168:402-412.

Wang JZ, Grundke-Iqbal I, Iqbal K (2007) Kinases and phosphatases and tau sites involved in Alzheimer neurofibrillary degeneration. Eur J Neurosci 25:59-68.

Watson GS, Craft S (2003) The role of insulin resistance in the pathogenesis of Alzheimer's disease: implications for treatment. CNS Drugs 17:27-45.

Weber C, Pernis B, Ting W, Rosenkrantz K, Reemtsma K (1984) Murine streptozotocin diabetes: influences of the major histocompatibility complex, genetic background and blood transfusion. Diabetologia 27 [Suppl]:160-162.

Williams SK, Howarth NL, Devenny JJ, Bitensky MW (1982) Structural and functional consequences of increased tubulin glycosylation in diabetes mellitus. Proc Natl Acad Sci USA 79:6546-6550.

Zhao YM, Pei JJ, Ji ZJ, Zhao ZW, Qian YY, Sheng SL (2003) Effect of amyloid precursor protein 17 mer peptide on microtubule structure and tau protein hyperphosphorylation in hippocampal neurons of experimental diabetic mice. NeuroReport 14:61-66.

Zhu X, Lee HG, Raina AK, Perry G, Smith MA (2002) The role of mitogenactivated protein kinase pathways in Alzheimer's disease. Neurosignals $11: 270-281$. 